$\mathrm{Y}-12$
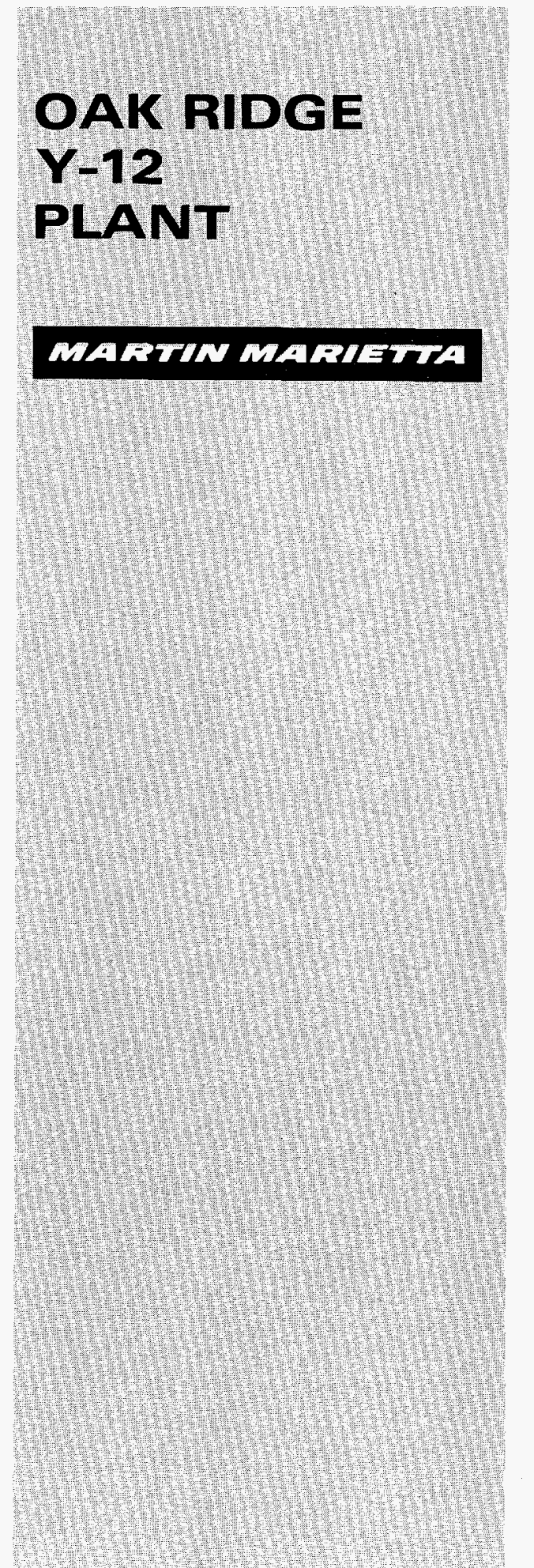

MANAGED BY

MARTIN MARIETTA ENERGY SYSTEMS, INC.

FOR THE UNITED STATES

DEPARTMENT OF ENERGY

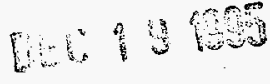

o 1

\section{Conversion and Blending Facility Highly Enriched Uranium to Low Enriched Uranium as Uranium Hexafluoride}

Nuclear Materials Disposition Program Office Defense Programs

July 5, 1995 


\section{DISCLAIMER}

This report was prepared as an account of work sponsored by an agency of the United States Government. Neither the United States Government nor any agency thereof, nor any of their employees, makes any warranty, express or implied, or assumes any legal liability or responsibility for the accuracy, completeness, or usefulness of any information, apparatus, product, or process disclosed, or represents that its use would not infringe privately owned rights. Reference herein to any specific commercial product, process, or service by trade name, trademark, manufacturer, or otherwise, does not necessarily constitute or imply its endorsement, recommendation, or favoring by the United States Government or any agency thereof. The views and opinions of authors expressed herein do not necessarily state or reflect those of the United States Government or any agency thereof. 


\section{DISCLAMMER}

Portions of this document may be illegible in electronic image products. Images are produced from the best available original document. 


\section{Predecisional Draft}

\section{Nuclear Materials Disposition Program Office Defense Programs}

\section{Conversion and Blending Facility Highly Enriched Uranium to Low Enriched Uranium as Uranium Hexafluoride}

July 5, 1995

Predecisional Draft

Oak Ridge Y-12 Plant managed by

Lockheed Martin Energy Systems, Inc.

for the U.S. Department of Energy under contract DE-AC05-84OR21400 
This page intentionally left blank. 


\section{CONTENTS}

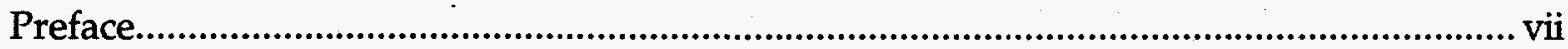

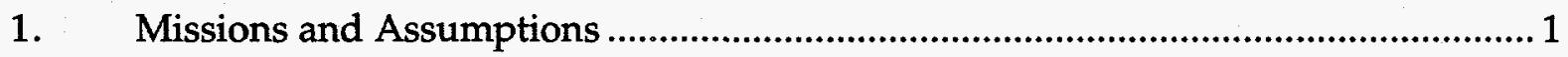

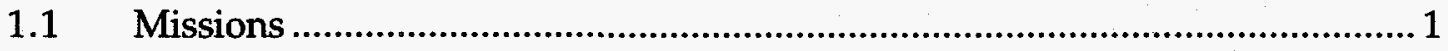

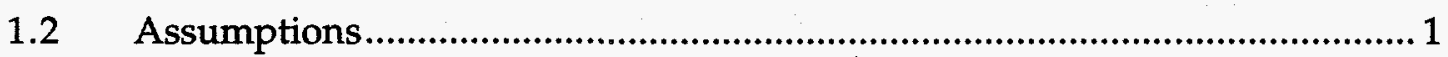

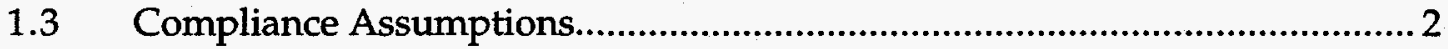

1.3.1 Rules, Regulations, Codes, and Guidelines..................................... 2

1.3.2 Safeguards and Security ....................................................... 2

1.3.3 Environmental, Safety, and Health ............................................... 3

1.3.3.1 Buffer Zones...................................................................3

1.3.3.2 Decontamination and Decommissioning.............................. 3

1.3.3.3 Toxicological/Radiological Exposure................................. 3

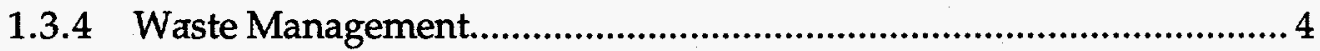

2. Conversion and Blending Facility Descriptions .............................................. 5

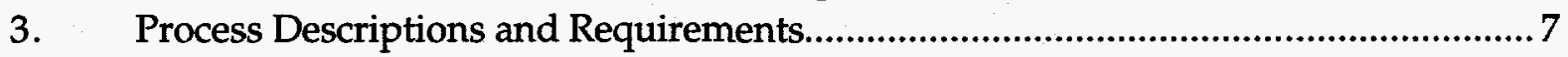

3.1 $\mathrm{UF}_{6}$ Blending Process Descriptions...................................................... 7

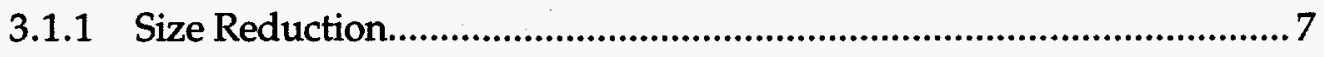

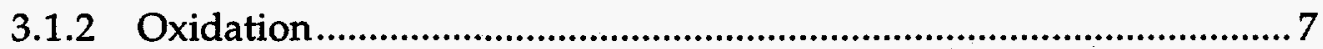

3.1.3 Dissolution........................................................................... 7

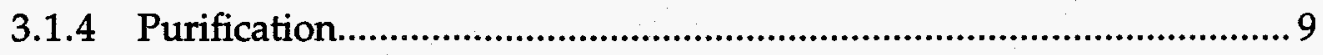

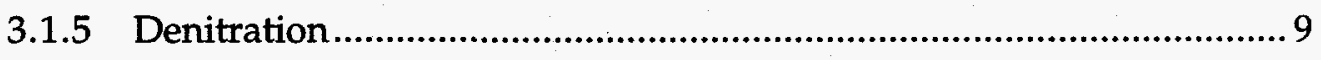

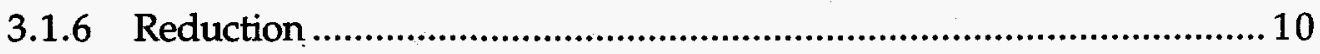

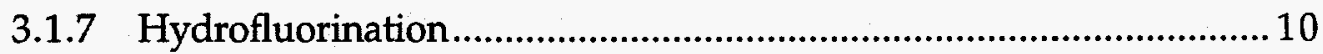

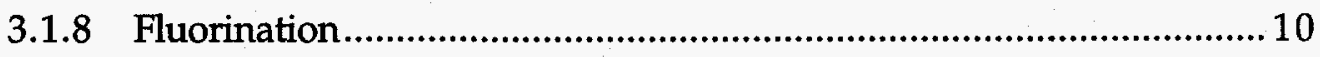

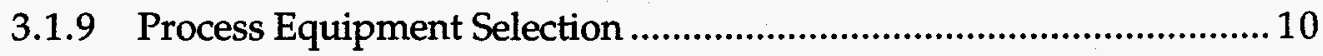

3.1.10 Assay Blending Operation....................................................... 10

3.1.10.1 Purity/Assay Verification - Feed ................................ 11

3.1.10.2 Vaporization of HEU................................................. 11

3.1.10.3 Vaporization of Blendstock .......................................... 11

3.1.10.4 Assay Blending............................................................ 11

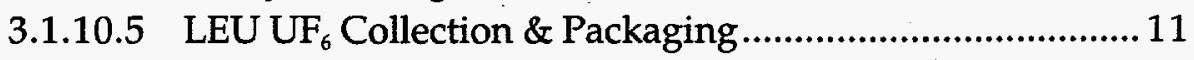

3.1.10.6 Purity/Assay Verification - Product.............................. 11

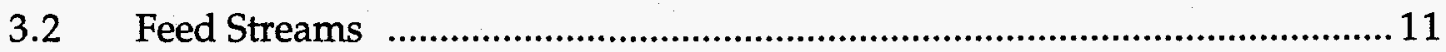

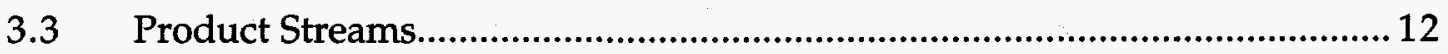

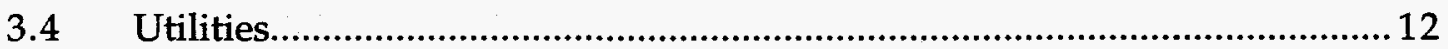

3.5 Chemicals/Materials Required for the Process ........................................ 12

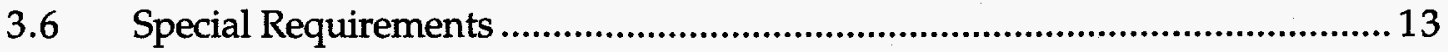

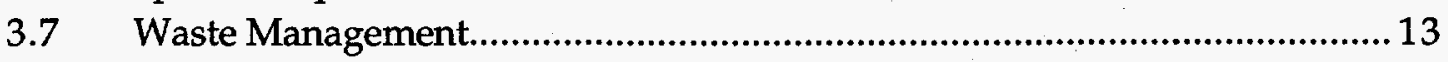


4. Resource Needs

4.1 Materials/Resources Consumed During Operation ..................................... 19

4.1.1 Utilities Consumed ................................................................... 19

4.1.2 Chemicals Consumed................................................................... 19

4.1.3 Radiological Materials Handled .................................................... 19

4.2 Materials/Resources Consumed During Construction.................................. 19

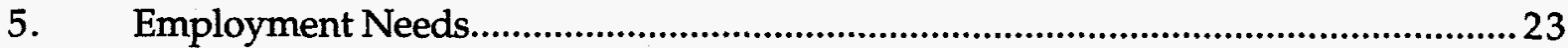

5.1 Employment Needs During Operation ..................................................... 23

5.1.1 Badged Employees at Risk of Radiological Exposure....................223

5.1.2 Labor Category Descriptions....................................................... 23

5.2 Employment Needs During Construction..............................................26

6. Waste and Emissions from the Plant ..................................................................29

6.1 Waste and Emissions During Operation..............................................29

6.1.1 Airborne Emissions........................................................................ 29

6.1.2 Solid and Liquid Waste ........................................................ 29

6.1.2.1 Radioactive Waste.........................................................29

6.1.2.2 Hazardous Waste........................................................... 29

6.1.2.3 Nonhazardous Waste......................................................2 29

6.2 Waste and Emissions Generated During Construction................................ 31

6.2.1 Airborne Emissions................................................................ 31

6.2.2 Solid and Liquid Waste ......................................................... 31

6.2.2.1 Hazardous Waste....................................................... 31

6.2.2.2 Nonhazardous Waste ......................................................... 31

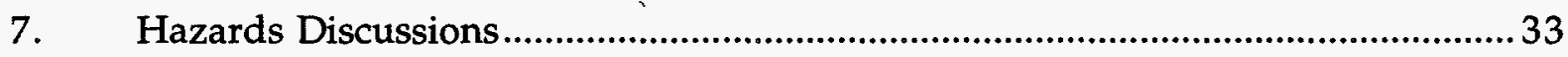

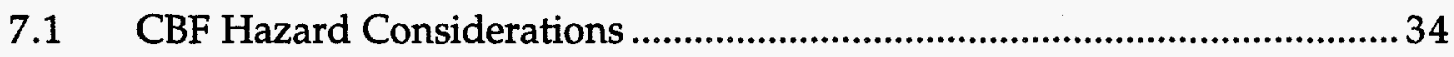

7.1.1 Materials at Risk................................................................ 34

7.1.1.1 Radioactive Hazardous Materials..................................... 34

7.1.1.2 Nonradioactive Hazardous Materials...............................37

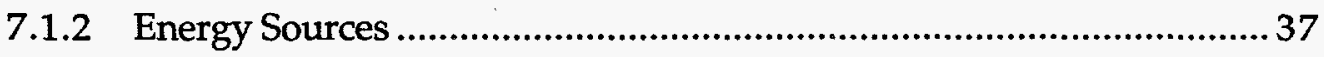

7.1.2.1 Fires and Explosions......................................................... 37

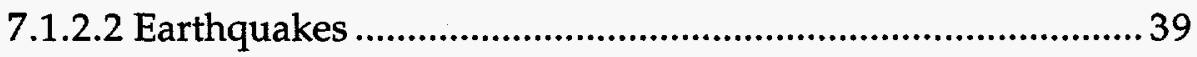

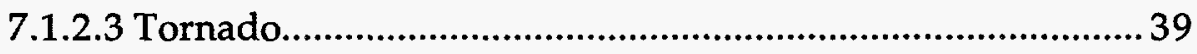

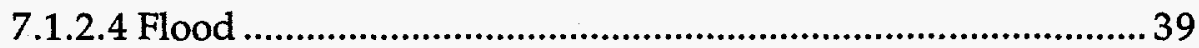

7.1.2.5 Nuclear Criticality...........................................................39

7.1.2.6 Process Design Related Events...............................................39

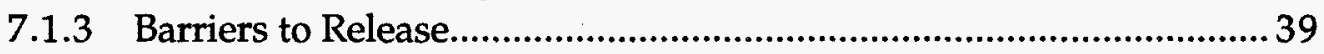

7.1.4 Protective Features..................................................................... 40

7.2. Accident Scenarios Considered .................................................................40

7.2.1 Earthquake....................................................................... 40

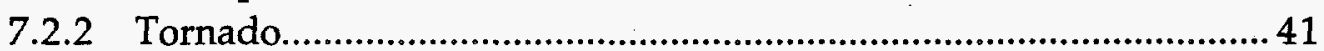

7.2 .3 Straight Wind ....................................................................... 41

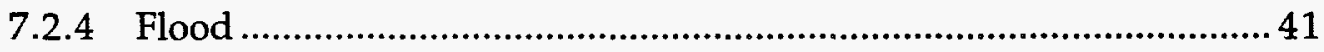




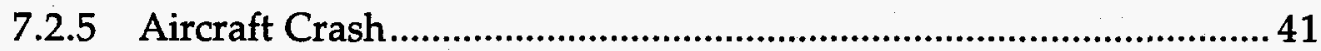

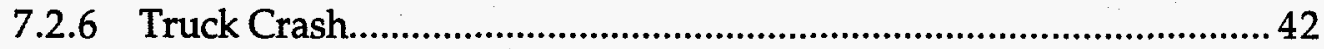

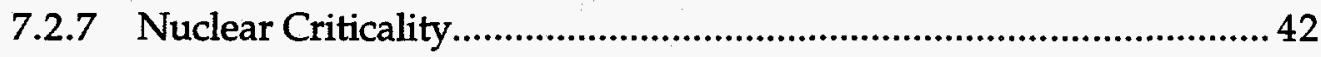

7.2.8 Process Related Accidents.................................................... 42

7.3 Selection of Bounding Accident Scenarios............................................... 43

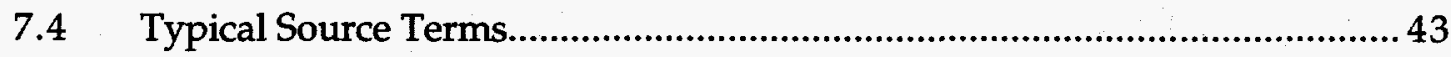

7.4.1 Releases from Fluid Bed System ................................................ 44

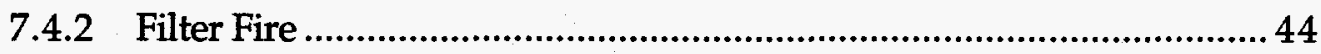

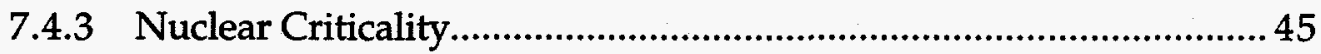

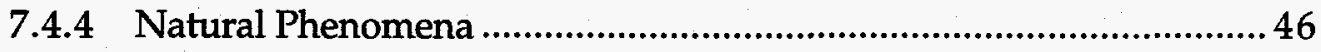

7.4.5 Solvent Extraction Fire..............................................................49 49

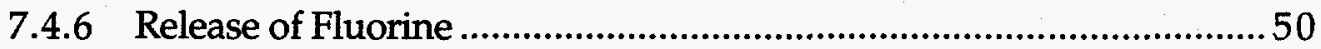

7.4.7 Release of Hydrogen Fluoride.................................................. 51

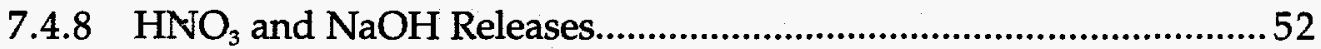

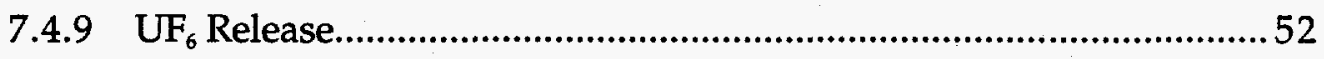

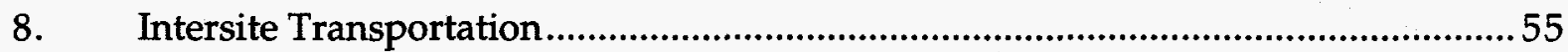

9. Acronyms, Abbreviations, and Initialisms....................................................5 57

Appendix A: Blending Assumptions and Limitations ................................................A-1

Distribution. 


\section{FIGURES}

Figure

3.1 Blending HEU as $\mathrm{UF}_{6}$ 8

3.2 Radioactive Liquid Waste Management Block Flow Diagram (UF ${ }_{6}$ )

3.3 Nonradioactive Liquid Waste Management Block Flow Diagram (UF $\left.{ }_{6}\right)$

3.4 Solid Waste Management Block Flow Diagram (UF $\left.{ }_{6}\right)$

A.1 Overall Blending Logic Diagram.

\section{TABLES}

Table

Title

Page

3.1 Waste Stream Identification a for $\mathrm{UF}_{6}$ Conversion and Blending Facility 14

4.1 Utilities Consumed During Operation - Annual 20

4.2 Chemicals Consumed During Operation - Annual. 21

4.3 Materials/Resources Consumed During Construction. 22

5.1 Employment During Surge Operation. 24

5.2 Number of Construction Employees Needed by Craft ..............................................2 27

6.1 Airborne Emissions During Operation - Annual ................................................... 30

6.2 Waste Volumes During Operation - Annual ........................................................... 30

6.3 Emissions During a Peak Construction Year............................................................ 32

6.4 Total Wastes Generated During Construction ......................................................32

7.1 Isotopic Content of Uranium at Various Enrichments..............................................35

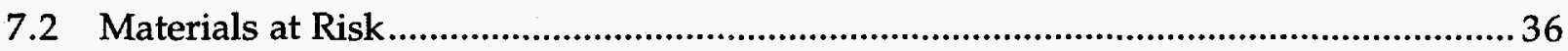

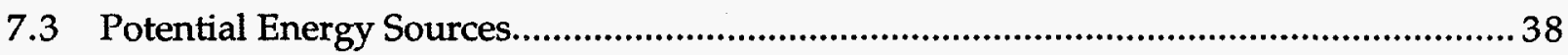

7.4 Typical Atmospheric Source Terms for Criticality.................................................47

8.1 Intersite Transportation Data - $\mathrm{UF}_{6}$ Blending ......................................................56

A.1 Assumptions for Surplus HEU Blending.......................................................... A-2

A.2 Feed Streams for Various Disposition Options ...................................................A-4 


\section{PREFACE}

The United States Department of Energy (DOE) is examining options for the disposition of surplus weapons-usable fissile materials and storage of all weapons-usable fissile materials. Disposition is a process of use or disposal of material that results in the material being converted to a form that is substantially and inherently more proliferation-resistant than is the original form. Examining options for increasing the proliferation resistance of highly enriched uranium (HEU) is part of this effort.

HEU is uranium (U) with a ${ }^{235} \mathrm{U}$ isotopic content greater than or equal to $20 \%$ of total uranium by weight $\left(20 \%{ }^{235} \mathrm{U}\right.$ assay). Blending HEU with depleted, natural, or low enriched uranium (LEU) diluent (called blendstock) has been proposed as a disposition option for HEU to permanently reduce enrichment. The resultant product is LEU, which has a ${ }^{235} \mathrm{U}$ assay less than $20 \%$ and is not weapons-usable. Any country or sub-national group would require uranium enrichment capability to re-enrich down-blended HEU. There are existing facilities in the United States that can provide HEU blending capabilities with little capital investment. This option mirrors similar dispositions actions taken by Russia. In addition to providing better resistance to proliferation, HEU blended to $3-5 \%{ }^{235} \mathrm{U}$ assay can be sold to the electric power generating industry for use as fuel for their light water reactors (LWR). The sale of this material can recover the cost of converting the HEU into such fuel and can provide additional revenue for the U.S. Treasury. High concentrations of minor uranium isotopes in some HEU inventories prevent the down-blended LEU product from meeting specifications for LWR fuel. Blending to allow assay for waste disposal is a viable approach for these inventories. Therefore, blending HEU to LEU for LWR fuel or waste disposal is an attractive disposition option.

On June 21, 1994 DOE published a Notice of Intent to prepare a Programmatic Environmental Impact Statement (PEIS) for the Long-Term Storage and Disposition of Weapons-Usable Fissile Materials. DOE is amending the scope of the PEIS by removing the disposition of all surplus HEU from the PEIS. Instead DOE will address the disposition of surplus HEU in a separate EIS. Four technologies for blending HEU will be assessed: blending as uranium hexafluoride $\left(\mathrm{UF}_{6}\right)$ to produce a $\mathrm{UF}_{6}$ product; blending as uranyl nitrate solutions to produce either a uranyl nitrate hexahydrate crystal (UNH) product or an oxide product; blending as oxide to produce an oxide product; and blending as molten metal to produce a cast metal product. The surplus HEU inventory is characterized by a variety of physical forms, chemical and isotopic impurities, and ${ }^{235} \mathrm{U}$ assays. Potential blendstock inventories exhibit similar characteristics. Any one of the proposed blending technologies has comparative advantages and disadvantages for blending select batches of HEU and blendstock materials. Inventory variability and the dual nature of the product destiny (LWR fuel or waste) make it unlikely that any one technology can provide for the disposition of all surplus HEU. 
This document provides data to be used in the environmental impact analysis for the $\mathrm{UF}_{6}$ blending HEU disposition option. This option provides a yearly HEU throughput of 10 metric tons (MT) with an average ${ }^{235} \mathrm{U}$ assay of $50 \%$ blended to $4 \%{ }^{235} \mathrm{U}$ assay LEU for LWR fuel. Since HEU exists in a variety of forms and not necessarily in the form to be blended, worst case scenarios for preprocessing prior to blending will be assumed for HEU feed streams. 


\section{MISSIONS AND ASSUMPTIONS}

\section{MISSIONS}

This Conversion and Blending Facility (CBF) will have two missions: (1) convert surplus HEU materials to pure HEU $\mathrm{UF}_{6}$ and (2) blend the pure HEU UF 6 with diluent $U_{6}$ to produce $L W R$ grade $L E U-U_{6}$. The primary emphasis of this blending operation will be to destroy the weapons capability of large, surplus stockpiles of HEU. The blended LEU product can only be made weapons capable again by the uranium enrichment process. The chemical and isotopic concentrations of the blended LEU product will be held within the specifications required for LWR fuel. The blended LEU product will be offered to the United States Enrichment Corporation (USEC) to be sold as feed material to the commercial nuclear industry.

\subsection{ASSUMPTIONS}

As described in Appendix A the function of this CBF is limited. In summary, the following assumptions apply.

- The assumed bounding case scenario for the CBF will be to extract impure $50 \%$ assay HEU from $40 \mathrm{MT}$ of uranium aluminum (U/Al) metal alloy, and to convert and blend down $10 \mathrm{MT}$ per year of the HEU to pure $4 \%$ assay $\mathrm{UF}_{6}$. The diluent feed used in the bounding case scenario will be pure $1.5 \%$ assay $\mathrm{UF}_{6}$.

- Blended LEU product will be $4.0 \%$ assay $\mathrm{UF}_{6}$ that meets American Society of Testing and Materials (ASTM) specifications for LWR fuel.

- Surplus HEU feed assumptions include:

- All surplus HEU feed will be above $20 \%$ assay.

- The levels of ${ }^{234} U$ and ${ }^{236} U$ isotopes in some $H E U$ feed will be sufficiently high to yield some LEU products that do not meet ASTM specifications for LWR fuel.

- Surplus HEU feed can be either pure or impure.

- Surplus HEU feed can be in any of the forms (1) metal and metal alloy, (2) uranium oxide or other uranium compounds, and (3) solutions. 
- Diluent uranium feed assumptions include:

- Diluent uranium feed can be either depleted uranium (DU), natural uranium (NU), or LEU.

- All diluent uranium feed will be in the form of $\mathrm{UF}_{6}$.

- No diluent uranium feed will require chemical purification prior to blending.

- General assumptions relating to the CBF include:

- All surplus HEU will be supplied from DOE inventories.

- Adequate supplies of uranium for diluent feed will be supplied by the USEC.

- New construction will be required for the CBF.

\subsection{COMPLIANCE ASSUMPTIONS}

\subsubsection{Rules, Regulations, Codes, and Guidelines}

1. New facility design or existing facilities comply with all applicable federal, state, and local laws and regulations. Additional industry consensus codes and standards are applied to the design as appropriate.

2. If new facilities or upgraded existing facilities are needed, structures, systems, and components are designed, fabricated, erected, and tested in accordance with the DOE Order 5700.6 series quality standards. These standards are commensurate with the risks associated with the facility and the significance of each structure, system, and component in mitigating releases of radioactive and other hazardous materials or minimizing risk. As low as reasonably achievable (ALARA) radiological exposure principles are incorporated appropriately throughout the design of the facilities.

\subsubsection{Safeguards and Security}

1. Programmatic Environmental Impact Statement (EIS) data do not include facility features to support International Atomic Energy Agency inspections or possible future treaty obligations.

2. Special Nuclear Material (SNM) will be safeguarded through the use of inprocess vaults that meet the intent of the requirements for production areas to be considered as nuclear material vault-type areas. 


\subsubsection{Environmental, Safety, and Health}

\subsubsection{Buffer Zones}

1. Existing site conditions may preclude compliance with the "greenfield" requirement for a 1-mile buffer zone between plant operations and the plant boundary. This requirement has been waived for existing facilities. However, public radiological exposure limits will be achieved and every effort will be made to maintain the present buffer zone for any new facilities that need to be constructed as part of the CBF.

2. Distances between any newly constructed modules/facilities are based on technical, safety, and security considerations.

\subsubsection{Decontamination and Decommissioning}

All facilities must consider and incorporate provisions for decontamination and decommissioning.

\subsubsection{Toxicological/Radiological Exposure}

1. Worker exposure to toxic agents will not exceed $80 \%$ of the regulatory standard. The ALARA process will be implemented in the design as it affects worker exposure to toxic agents.

2. Worker exposure to radiation will not exceed an annual dose of 1.0 rem effective dose equivalent (EDE). The goal for the CBF for worker radiation exposure is 0.5 rem EDE per year. The ALARA process will be implemented in the design for radiation exposure of workers.

3. Public exposure to radiation at the site boundary from routine operations will not exceed 100 millirem EDE per year per DOE 5400.5, Radiological Protection of the Public and Environment and the Radiological Control Manual. The goal for the CBF for public radiation exposure is 1 millirem EDE per year. The ALARA process will be implemented in the design for radiation exposure of the public.

4. The goal is for all facilities to be operated such that operators are not required to wear respiratory protection to meet radiological exposure limits while conducting routine operations.

5. The number of personnel required to work in contaminated areas is minimized and controlled.

6. The use of carcinogens is minimized or eliminated, where possible. 


\subsubsection{Waste Management}

Waste treatment and disposal associated with the CBF will occur on-site or off-site at approved facilities. The following waste management assumptions may apply to the CBF depending on site requirements:

1. Generation of all wastes is minimized subject to the constraints of ALARA.

2. Mixed low-level waste (mixed LLW) is burned in approved local incinerators or stabilized and stored on-site on a long-term basis as LLW until regulations allow disposal.

3. LLW disposal in a permitted site.

4. Unclassified hazardous waste is sent to an authorized Resource Conservation and Recovery Act (RCRA) site for treatment and/or disposal.

5. Sanitary wastewater is treated in a permitted facility.

6. Sanitary and industrial solid waste is disposed of in a permitted landfill. 


\section{CONVERSION AND BLENDING FACILITY DESCRIPTIONS}

The UF $\mathrm{UF}_{6}$ Conversion and Blending Facility will probably use existing facilities at a plant location that already has support infrastructure in place. In addition, a new facility for fluorination will be constructed adjacent to the existing facility. The overall facility will be a multistory structure that contains all of the operations needed to convert and blend HEU in a variety of forms and assays into $4 \%{ }^{225} \mathrm{U}$ assay $\mathrm{UF}_{6}$. The facility will be divided into radiological and nonradiological areas. Radiological areas will be divided into areas for processing and storing Category I quantities of SNM and areas for non-SNM. Further division of the areas will be process related. Specifically, storage areas will be separated from processing areas.

The facility must be capable of receiving blending materials. A dock for Safe Secure Trailers (SSTs) is required for receiving HEU. A separate dock is required for receiving blendstock materials and shipping blended product.

Facilities that contain significant amounts of hazardous materials (radioactive materials being a category of hazardous materials) are classified by DOE as category 1, 2 or 3 hazard facilities. Facilities that contain significant amounts of radioactive materials are classified by DOE as "nuclear facilities." The design criteria for hazard classified nuclear facilities are defined in DOE Order 6430.1A, DOE Order 5480.28, and DOE-STD-1020-94. New facility design and construction must meet these criteria. Existing facilities must meet the intent of this criteria. Facilities at non-DOE sites must be licensed by the Nuclear Regulatory Commission (NRC) and must meet equivalent NRC criteria.

This facility will have the following features and capabilities:

1. Redundancy and safety-class systems, as defined in DOE 6430.1A, to maintain building atmospheres during natural phenomena events and credible accident scenarios

2. Three major power systems (uninterruptible power, standby power, and emergency power) to provide safe shutdown and containment (during and after accidents)

3. One or more Material Access Areas (MAAs) for proper safeguards and security of the HEU materials

4. One or more radiation control areas where personnel access and egress will be controlled 
5. Heating, ventilation, and air conditioning (HVAC) systems that comply with DOE 6430.1A criteria for containment and filtration

6. Location in a protected area (such as PIDAS at the $Y-12$ plant) that complies with DOE safeguards and security requirements 


\section{PROCESS DESCRIPTIONS AND REQUIREMENTS}

\subsection{UF 6 BLENDING PROCESS DESCRIPTIONS}

Criticality safety considerations require that safe handling, transfer, and storage practices be observed for HEU materials. Processing equipment will be designed for safe geometry to avoid dependence upon administrative controls to prevent any possibility of a criticality accident. Processing paths for this blending option are outlined in Figure 3.1. The bounding process, described in this report, is highlighted on Figure 3.1.

\subsubsection{Size Reduction}

The sizes and shapes of HEU feed materials will vary. Size reduction is required for two principle purposes: to produce roughly uniform size pieces to facilitate process handling and protect process equipment; and to facilitate oxidation or dissolution. Size reduction can be accomplished by crushing, machining to chips or turnings, or by rolling and shearing. Propylene glycol is used as a machine coolant during this process. Nitrogen may be used as a cover (blanket) gas.

\subsubsection{Oxidation}

Oxidation of uranium is an exothermic reaction carried out at elevated temperature using air. A heated rotating kiln can be used. The uranium oxide product is a powder and is generally preferred over metal for nitric acid dissolution, although the size reduced metal can be dissolved in nitric acid directly. With the uranium converted to oxide, alternative paths for conversion to $\mathrm{UF}_{6}$ are available. If purification is not required, the $\mathrm{U}_{3} \mathrm{O}_{8}$ may be fluorinated directly to $\mathrm{UF}_{6}$ as described in Subsection 3.1.8.

\subsubsection{Dissolution}

Dissolution of the $\mathrm{U} / \mathrm{Al}$ alloy requires a two-step process. The first step separates the aluminum from the uranium by dissolving the aluminum in a solution containing $15 \%$ sodium hydroxide, $10 \%$ sodium nitrate, and approximately $1 \%$ barium nitrate. The aluminum is dissolved as sodium aluminate and the uranium forms a sodium diurante precipitate. The precipitate is dissolved in nitric acid in the second step.

The sodium diuranate precipitate from the first step, as well as other uranium oxides or size reduced metal, are dissolved in nitric acid $\left(\mathrm{HNO}_{3}\right)$. The aqueous solution of uranyl nitrate, $\left[\mathrm{UO}_{2}\left(\mathrm{NO}_{3}\right)_{2} \bullet x \mathrm{H}_{2} \mathrm{O}\right]$, may contain other impurities present in the HEU being processed. Impure uranyl nitrate solutions are purified as described in 


\section{Bounding Case}

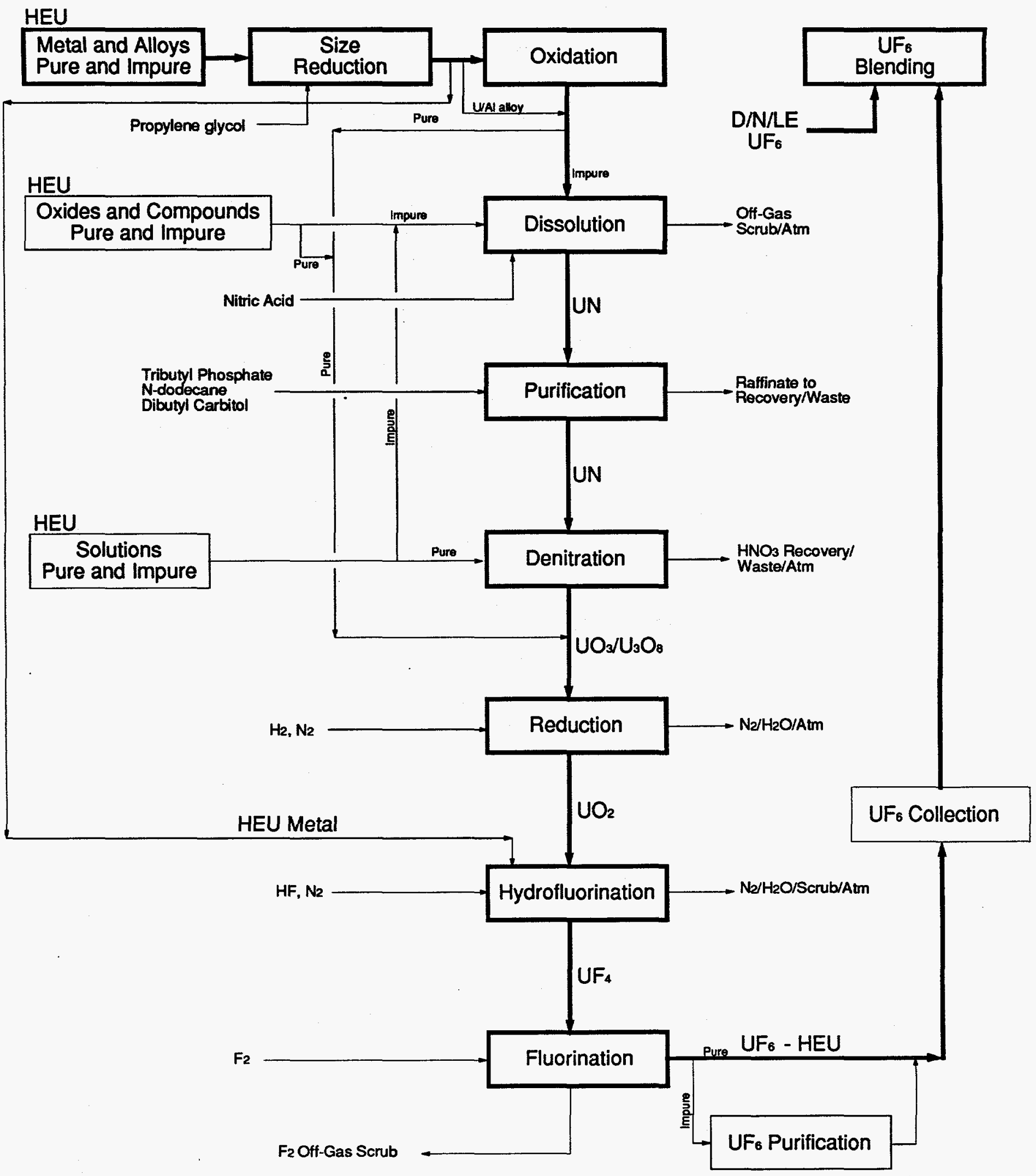

Figure 3.1 - Blending HEU as UF6 
Subsection 3.1.4. Hazardous nitrogen oxides are co-products of the nitric acid dissolution process. These emissions are scrubbed with water prior to release for nitric acid recovery.

\subsubsection{Purification}

Purification of the uranyl nitrate solution consists of a two step solvent extraction process. The uranyl nitrate transfers selectively from the aqueous uranyl nitrate solution into the immiscible organic extraction medium leaving impurities in the aqueous medium. The pure uranyl nitrate is then transferred back to an aqueous stripping solution and subsequently it is concentrated by evaporation before denitration.

Primary Extraction. The impure uranyl nitrate/nitric acid solution (additional nitric acid may be added to the solution from the nitric acid dissolution step) is fed to a counterflow extraction column where the uranyl nitrate is extracted into a countercurrent flow of organic solvent (dibutyl carbitol). The resulting aqueous raffinate containing the impurities from this extraction column is tested to ensure the uranium content is $<25 \mathrm{ppm}$ before the raffinate is sent to a waste treatment and disposal facility for recovery of nitric acid and other treatment. The organic stream is then contacted with dilute nitric acid in a strip column to back-extract (strip) the uranyl nitrate from the solvent, producing a dilute uranyl nitrate/nitric acid stream which is concentrated in the primary and intermediate evaporators.

Secondary Extraction. The product from the primary extraction/evaporation step requires the addition of nitric acid before the stream is fed to the secondary extraction column where it is contacted by a countercurrent flow of solvent consisting of tributyl phosphate (TBP) in a N-dodecane (or high-grade kerosene) diluent. The resulting uranyl nitrate-TBP complex is then contacted by a countercurrent flow of dilute nitric acid in the secondary strip column to strip the uranyl nitrate from the solvent. The dilute uranyl nitrate/nitric acid solution produced in the strip column is concentrated in the secondary evaporators. The raffinate form the secondary extraction column is routed to the primary columns for further processing.

\subsubsection{Denitration}

Denitration is a thermal decomposition process in which the concentrated uranyl nitrate hexahydrate is decomposed in a heated rotary kiln to form $\mathrm{UO}_{3}$. The off-gas, generated by the decomposition reaction, is scrubbed with water to remove the hazardous nitrous oxide gases and recover nitric acid. 


\subsubsection{Reduction}

Although the $\mathrm{UO}_{3}$ product of the oxidation step can be directly fluorinated to $\mathrm{UF}_{6}$ using elemental fluorine gas, reduction of the $\mathrm{UO}_{3}$ with hydrogen at $600^{\circ} \mathrm{C}$ converts it to $\mathrm{UO}_{2}$ which can be hydrofluorinated to $\mathrm{UF}_{4}$ using hydrogen fluoride $(\mathrm{HF})$.

\subsubsection{Hydrofluorination}

The hydrofluorination of $\mathrm{UO}_{2}$ to $\mathrm{UF}_{4}$ uses $\mathrm{HF}$ gas as the fluorinating agent. $\mathrm{HF}$ is significantly less expensive than fluorine gas which, for this process, would be required only to add the last two fluorine atoms to $\mathrm{UF}_{4}$ to produce $\mathrm{UF}_{6}$. The exhaust from this fluid bed and the fluid bed described in Subsection 3.1.6 will be routed through multiple filters in series to trap entrained HEU. The exhaust from these filters is monitored before release with a gamma detector. The off-gas is scrubbed with potassium hydroxide $(\mathrm{KOH})$ to capture any $\mathrm{HF}$ before the gases are released.

\subsubsection{Fluorination}

Direct fluorination of $\mathrm{UO}_{3}$ or $\mathrm{U}_{3} \mathrm{O}_{8}$ to $\mathrm{UF}_{6}$ (paragraph 3.1.2) requires elemental fluorine $\left(\mathrm{F}_{2}\right)$ which is produced from $\mathrm{HF}$ in electrolytic fluorine cells or is purchased in fluorine cylinders. Fluorination of $\mathrm{UF}_{4}$ to $\mathrm{UF}_{6}$ requires only one third as much elemental fluorine as total fluorination of $\mathrm{UO}_{3}$ or $\mathrm{U}_{3} \mathrm{O}_{8}$ to $\mathrm{UF}_{6}$ using $\mathrm{F}_{2}$. The off-gas is scrubbed with $\mathrm{KOH}$ to capture $\mathrm{F}_{2}$ after the $\mathrm{UF}_{6}$ is captured and before the reamining gases are released. The $U_{6}$ is collected (captured) in a series of cold traps. A sodium fluoride $(\mathrm{NaF})$ trap catches any $\mathrm{UF}_{6}$ breaking through the cold traps.

\subsubsection{Process Equipment Selection}

Fluid bed reactors are frequently used for process reactions between solid and gas phase reactants. These reactions include those between uranium oxides and hydrogen, $\mathrm{HF}$, and $\mathrm{F}_{2}$ and $\mathrm{UF}_{4}$ and $\mathrm{F}_{2}$. A potential problem arises when $\mathrm{HEU}$ compounds are processed; criticality safe process vessel diameters are limited to about five inches for handling HEU. Such small equipment may be found undesirable or unsuitable for fluid bed reactors and may lead to consideration of alternative reaction vessels such as rotary kiln type reactors, stirred bed reactors, or flame towers.

\subsubsection{Assay Blending Operation}

The UF $\mathrm{UF}_{6}$ assay blending operation blends the purified $\mathrm{HEUU}_{\mathrm{UF}}$ with existing $\mathrm{UF}_{6}$ blendstock. 


\subsubsection{Purity/Assay Verification - Feed}

The purity/assay verification samples can be taken from the individual HEU and blendstock $\mathrm{UF}_{6}$ streams prior to blending to ensure that the purity and assays are acceptable.

\subsubsection{Vaporization of HEU}

The HEU vaporization process vaporizes the $\mathrm{HEU} \mathrm{UF}_{6}$ in an autoclave designed for HEU applications.

\subsubsection{Vaporization of Blendstock}

The blendstock vaporization process vaporizes the $\mathrm{UF}_{6}$ blendstock in an autoclave that is larger in capacity and designed for larger capacity LEU UF 6 cylinders (less than $5 \%$ assay).

\subsubsection{Assay Blending}

The two $\mathrm{UF}_{6}$ components (HEU and blendstock) are blended in precise ratios to achieve the desired ${ }^{25} \mathrm{U}$ assay in the blended product.

\subsubsection{LEU UF 6 Collection \& Packaging}

The LEU UF ${ }_{6}$ collection and packaging process collects the blended material in cold traps and transfer it (as liquid) into existing Department of Transportation (DOT) - approved shipping cylinders.

\subsubsection{Purity/Assay Verification - Product}

The product cylinders is heated in a containment autoclave for homogenization prior to liquid sampling for purity and assay verification.

\section{$3.2 \quad$ FEED STREAMS}

The $\mathrm{UF}_{6}$ blending scenario has two feed streams:

1. Pure and impure HEU metal, alloys, solutions, and compounds with an average ${ }^{235} \mathrm{U}$ assay of $50 \%$ (bounding case is alloy with $75 \%$ aluminum and $25 \%$ uranium).

2. Pure DU, NU, LEU UF 6 blendstock (bounding case is $1.5 \%{ }^{255} \mathrm{U}$ assay). 


\subsection{PRODUCT STREAMS}

The $\mathrm{UF}_{6}$ blending scenario has one product stream, pure LEU $\mathrm{UF}_{6}$ with $\mathrm{a}^{255} \mathrm{U}$ assay of $4 \%$ (bounding case).

\subsection{UTILITIES REQUIRED}

The $\mathrm{UF}_{6}$ blending scenario requires the following utility services:

- Electricity

- Water for fire protection

- Sanitary water

- Tower cooling water

- Chilled water

- Steam

- Compressed air/breathing air

- Compressed gases

- Telecommunications

\subsection{CHEMICALS/MATERIALS REQUIRED FOR THE PROCESS}

The bounding case requires the following chemicals/materials:

- Nitric acid

- Dibutyl carbitol

- Sodium fluoride

- N-dodecane (or high-grade kerosene)

- Sodium hydroxide

- Sodium nitrate

- Barium nitrate

- Tributyl phosphate

- Potassium hydroxide

- Hydrogen

- Argon

- Fluorine

- Nitrogen

- Anhydrous hydrogen fluoride

- Propylene glycol 


\subsection{SPECIAL REQUIREMENTS}

The following special requirements apply to this process:

1. Radiological hazard protection for internal (inhalation/ingestion) exposures to alpha particles from uranium

2. Criticality safety in all phases of material handling, process design, and accident analysis, with safe geometry as the preferred method of criticality control

3. Safeguards and security issues associated with personnel access to and the handling, transportation, and disposal of classified data related to uranium processes and associated with protection of special nuclear material from theft, diversion, or sabotage

4. Consideration of pyrophoric properties of finely divided uranium metal

5. Design of equipment, processes, and storage systems for a rapid and accurate periodic SNM inventory determination

6. Elimination or reduction of the use or generation of hazardous materials to minimize the generation of mixed radiological/hazardous waste streams

7. Attention to maximization of by-product recycle to reduce the opportunity for radiological waste genèration

8. Consideration of human factor designs, especially in the handling of large, high-density uranium parts and materials

9. Consideration of the need for classified shape processing

10. Design to reduce material oxidation and provide dust control

11. Considerations for the handling and processing of $\mathrm{HF}$ and $\mathrm{F}_{2}$

\subsection{WASTE MANAGEMENT}

Table 3.1 lists solid and liquid waste streams. Low-level (RAD), mixed (MIX), hazardous (HAZ), and sanitary (SAN) wastes are included. Included in the table are the proposed treatment, storage, and disposal methods. Figures 3.2, 3.3, and 3.4 depict, in block flow format, the proposed treatment of various waste streams of the $\mathrm{CBF}$. 
Table 3.1 Waste Stream Identification for $\mathrm{UF}_{6}$ Conversion and Blending Facility

\begin{tabular}{|c|c|c|c|c|c|c|c|}
\hline Wy- & Wy & $\%$ & $16 \%$ & why & xy. & 1\% & (1) \\
\hline HAZ-1 & $\begin{array}{l}\text { Liquid Waste Treatment Excess/ } \\
\text { Flush Water }\end{array}$ & $5,700 \mathrm{~L} / \mathrm{yr}$ & distillation, evaporation & neutralization & long-term & surface water & liquid waste treatment \\
\hline HAZ-2 & Chemical Spillage & $270 \mathrm{~L} / \mathrm{yr}$ & none & incineration & long-term & none & chemical receiving \\
\hline MIX-1 & Liquid Lab Waste & $950 \mathrm{~L} / \mathrm{yr}$ & none & $\begin{array}{l}\text { incineration \& } \\
\text { immobilization }\end{array}$ & long-term & none & lab analyses \\
\hline MIX-2 & Sump Collection Wastes & $9,100 \mathrm{~L} / \mathrm{yr}$ & none & $\begin{array}{l}\text { precipitation, } \\
\text { filtration, } \& \\
\text { immobilization }\end{array}$ & long-term & surface water & facility cleanup \\
\hline MIX-3 & Spent Solvent & $46 \mathrm{~L} / \mathrm{yr}$ & cleaning, recycle & incineration & none & none & purification process \\
\hline MIX-4 & Solvent-Contaminated Aqueous Waste & $6,800 \mathrm{~L} / \mathrm{yr}$ & distillation & $\begin{array}{l}\text { organics removal } \\
\text { \& immobilization }\end{array}$ & longterm & surface water & solvent treatment \\
\hline MIX-5 & Raffinate & $142,000 \mathrm{~L} / \mathrm{yr}$ & acid recovery & $\begin{array}{l}\text { neutralization \& } \\
\text { volume reduction, } \\
\text { \& immobilization }\end{array}$ & long-term & LLW burial & $\begin{array}{l}\text { purification, denitration, } \\
\text { offgas scrubber }\end{array}$ \\
\hline RAD1 & Decontamination Wastewater & $34,000 \mathrm{~L} / \mathrm{yr}$ & none & $\begin{array}{l}\text { uranium recovery } \\
\text { effluent treatment, } \\
\text { \& immobilization }\end{array}$ & long-term & surface water & decontamination \\
\hline RAD-2 & $10 \%$ Propylene Glycol, 90\% Water & $15,000 \mathrm{~L} / \mathrm{yr}$ & none & $\begin{array}{l}\text { incineration \& } \\
\text { immobilization }\end{array}$ & long-term & none & size reduction \\
\hline RAD3 & Decontamination Solids & $12 \mathrm{~m}^{2} / \mathrm{yr}$ & none & $\begin{array}{l}\text { uranium recovery } \\
\text { immobilization }\end{array}$ & long-term & LLW burial & decontamination \\
\hline RAD4 & Solid Lab Waste & $0.1 \mathrm{~m}^{3} / \mathrm{yr}$ & none & immobilization & long-term & LLW burial & lab analyses \\
\hline RAD.5 & Scrapped Equipment & $51 \mathrm{~m}^{3} / \mathrm{yr}$ & decontamination & none & long-term & LLW burial & decontamination \\
\hline RAD6 & HEPA Filters & $24 \mathrm{~m}^{3} / \mathrm{yr}$ & none & volume reduction & long-term & LLW burial & offgas filtration \\
\hline RAD.7 & Miscellaneous Contaminated Solids & $57 \mathrm{~m}^{3} / \mathrm{yr}$ & none & volume reduction & longterm & LLW burial & facility operations \\
\hline RAD-8 & Air Sampling Filters & $0.03 \mathrm{~m}^{2} / \mathrm{yr}$ & none & volume reduction & long-term & LLW burial & offgas sampling \\
\hline RAD-9 & Sintered-Metal Filter Cartridges & $0.06 \mathrm{~m}^{2} / \mathrm{yr}$ & none & volume reduction & long-term & LLW burial & offgas filtration \\
\hline RAD-10 & Contaminated Calcium Fluoride & $0.9 \mathrm{~m}^{2} / \mathrm{yr}$ & drying & immobilization & long-erm & LLW burial & scrubber blowdown treatment \\
\hline RAD-11 & Spent Sodium Fluoride & $0.03 \mathrm{~m}^{3} / \mathrm{yr}$ & none & immobilization & long-term & LLW burial & UF6 traps \\
\hline SAN-1 & Sanitary Sewage & $18,000,000 \mathrm{~L} / \mathrm{yr}$ & none & $\begin{array}{l}\text { biologica! } \\
\text { treatment }\end{array}$ & none & $\begin{array}{l}\text { surface water, } \\
\text { sanitary landfill }\end{array}$ & facility operations \\
\hline SAN-2 & Cooling Tower Blowdown & $163,000 \mathrm{~L} / \mathrm{yr}$ & none & dechlorination & none & surface water & RCW system \\
\hline SAN-3 & Condensate Blowdown & $984,000 \mathrm{~L} / \mathrm{yr}$ & none & none & none & surface water & denitration process, area heat \\
\hline SAN-4 & Contaminated Rainwater & $2,650 \mathrm{~L} / \mathrm{yr}$ & none & incineration & none & none & chemical receiving \\
\hline SAN-5 & Sanitary Solid Waste & $820 \mathrm{~m}^{3} / \mathrm{yr}$ & none & none & none & sanitary landfill & facility operations \\
\hline SAN-6 & Autoclave Condensate Blowdown & $2,900 \mathrm{~L} / \mathrm{yr}$ & none & none & none & surface water & UF6 vaporization \\
\hline SAN-7 & Uncontaminated Calcium Fluoride & $0.5 \mathrm{~m}^{2} / \mathrm{yr}$ & drying & none & none & sanitary landfill & scrubber blowdown treatment \\
\hline
\end{tabular}




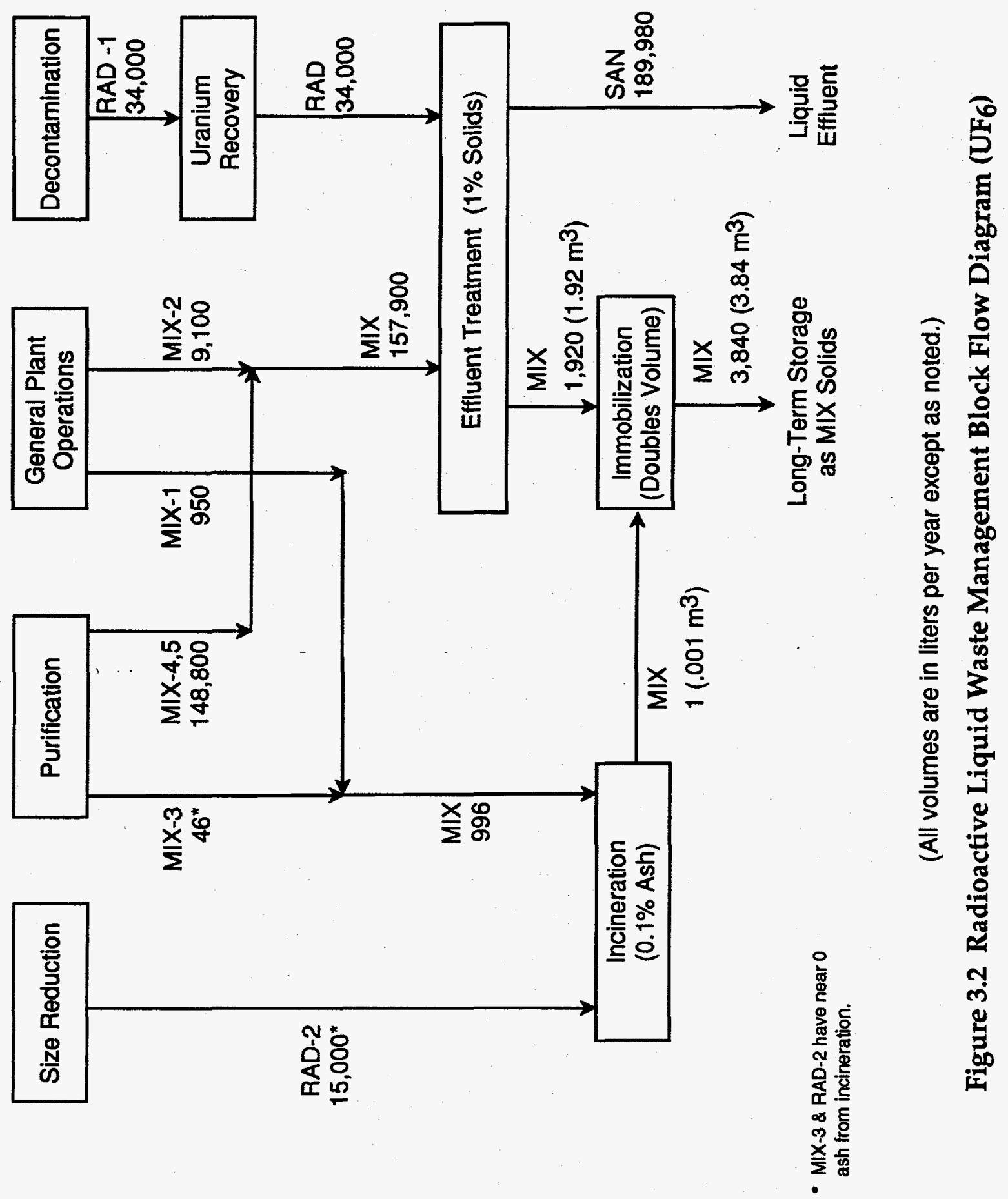




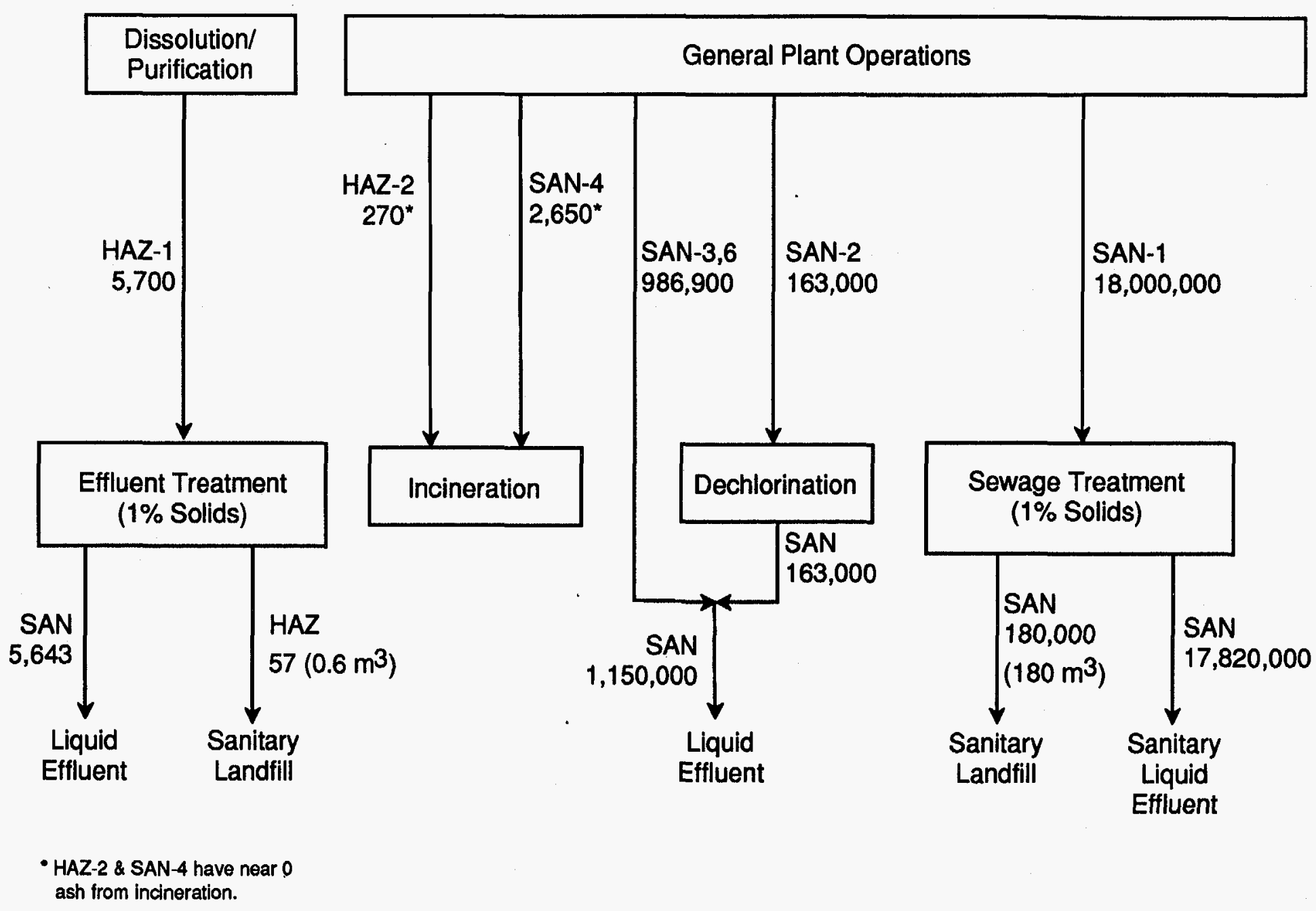

Figure 3.3 Nonradioactive Liquid Waste Management Block Flow Diagram (UF6) 


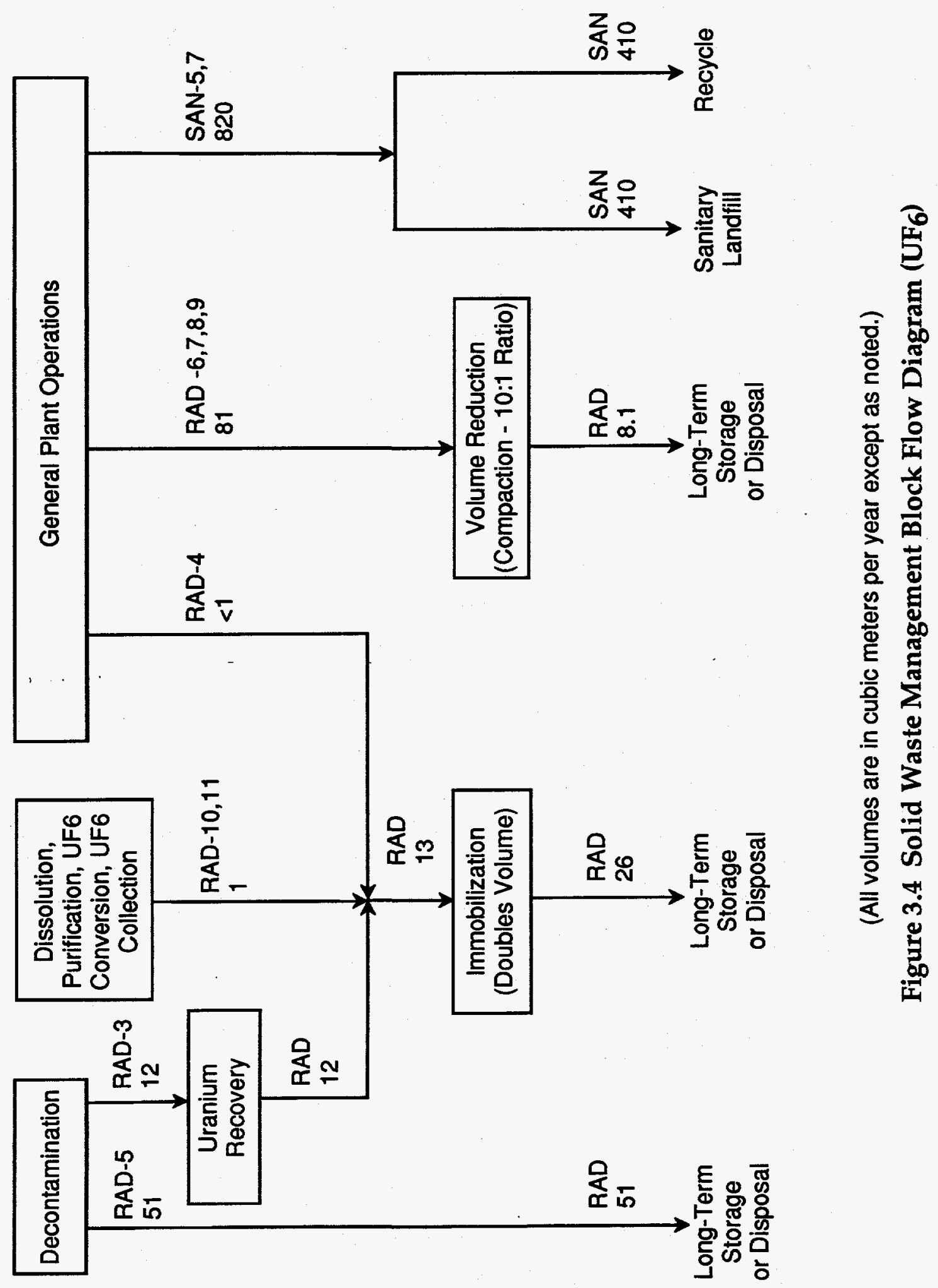


This page intentionally left blank. 


\section{RESOURCE NEEDS}

\subsection{MATERIALS/RESOURCES CONSUMED DURING OPERATION}

\subsubsection{Utilities Consumed}

Table 4.1 shows the utilities consumed annually during operation.

\subsubsection{Chemicals Consumed}

Solid, liquid, and gaseous chemical requirements are summarized in Table 4.2.

\subsubsection{Radiological Materials Handled}

Radiological materials handled in the CBF include uranium materials at all assay levels and in a variety of forms (e.g., metal, alloy, oxide, solutions, etc.).

4.2 Materials/Resources Consumed During Construction

Table 4.3 indicates the materials/resources consumed during construction. 
Table 4.1. Utilities consumed during operation - annual

\begin{tabular}{|c|c|c|}
\hline 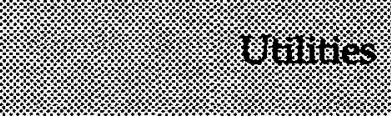 & 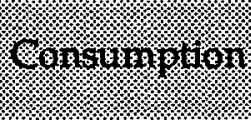 & (y) \\
\hline Electricity (MWh) & 25,000 & $2 \mathrm{MW}$ \\
\hline Diesel fuel (gal) & 15,000 & \\
\hline Natural gas ${ }^{b}$ (scf) & 750,000 & \\
\hline Coal (ton) & 600 & \\
\hline Raw water (gal) & $25 \times 10^{6}$ & \\
\hline
\end{tabular}

- Peak demand is the maximum rate expected during any hour.

b Standard cubic feet measured at 14.7 psia and $60^{\circ} \mathrm{F}$. 
Table 4.2. Chemicals consumed during operation - annual

\begin{tabular}{|c|c|c|}
\hline (anernigr: & Oranivi: & 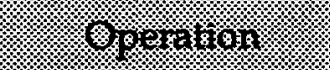 \\
\hline \multicolumn{3}{|c|}{ SOLID CHEMICALS } \\
\hline Potassium hydroxide & $6.0 \mathrm{MT}$ & Waste treatment $^{2}$ \\
\hline Barium nitrate & $3.5 \mathrm{MT}$ & Dissolution $^{\mathbf{b}}$ \\
\hline Sodium hydroxide & $1.0 \mathrm{MT}$ & Purification \\
\hline Sodium fluoride & $0.1 \mathrm{MT}$ & $\mathrm{UF}_{6}$ Collection \\
\hline \multicolumn{3}{|c|}{ LIQUID CHEMICALS } \\
\hline Propylene glycol & $1600 \mathrm{~kg}$ & Size reduction \\
\hline Sodium hydroxide, $50 \%$ by weight & $60 \mathrm{MT}$ & $\begin{array}{l}\text { Dissolution and } \\
\text { waste treatment }{ }^{c}\end{array}$ \\
\hline Sodium nitrate, $40 \%$ by weight & $40 \mathrm{MT}$ & Dissolution $^{\mathrm{d}}$ \\
\hline Nitric acid, new, $30 \%$ by weight & $20 \mathrm{MT}$ & $\begin{array}{l}\text { Dissolution and } \\
\text { purification }\end{array}$ \\
\hline Nitric acid, recovered, $30 \%$ & $20 \mathrm{MT}$ & Dissolution ${ }^{*}$ \\
\hline Dibutyl carbitol & $400 \mathrm{~kg}$ & Purification \\
\hline TBP & $50 \mathrm{~kg}$ & Purification \\
\hline $\mathrm{N}$-dodecane (or high-grade kerosene) & $1.5 \mathrm{MT}$ & Purification \\
\hline \multicolumn{3}{|c|}{ GASEOUS CHEMICALS } \\
\hline Hydrogen & $40,000 \mathrm{scf}(105 \mathrm{~kg})$ & HEU Reduction \\
\hline Anhydrous hydrogen fluoride & $4.0 \mathrm{MT}$ & $\begin{array}{l}\text { HEU } \\
\text { hydrofluorination }\end{array}$ \\
\hline Fluorine & $2.0 \mathrm{MT}$ & HEU fluorination \\
\hline Argon & $10^{5} \mathrm{scf}$ & Blanket gas \\
\hline Nitrogen & $10^{5} \mathrm{scf}$ & Blanket gas \\
\hline
\end{tabular}

For scrubbing the denitration, hydrofluorination, and fluorination offgases.

b Used to precipitate otherwise soluble carborates.

c For dissolution of the U/ $\mathrm{Al}$ alloy and for neutralizing the unrecovered nitric acid in the purification operation raffinate.

d Used to suppress the evolution of hydrogen during the dissolution of Al by sodium hydroxide.

e New nitric acid supplements recovered nitric acid as needed in dissolution of the U; purification uses only new nitric acid. 
Table 4.3. Materials/resources consumed during construction

\begin{tabular}{|c|c|c|}
\hline 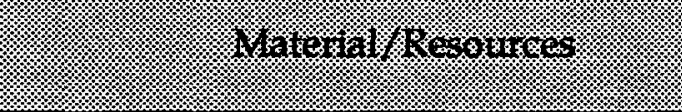 & 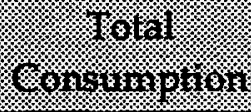 & $l_{14}^{4}$ \\
\hline Electricity (MW) & & $0.5 \mathrm{MW}$ \\
\hline Water (gal) & $3 \times 10^{6}$ & \\
\hline Concrete $\left(\mathrm{yd}^{3}\right)$ & 1,000 & \\
\hline Steel (ton) & 500 & \\
\hline Gasoline, diesel fuel, and lube oil (gal) & 20,000 & \\
\hline Industrial gases $^{\mathrm{b}}$ (scf) & 108,000 & \\
\hline
\end{tabular}

a Peak demand is the maximum rate expected.

b Sandard cubic feet measured at 14.7 psia and $60^{\circ} \mathrm{F}$. 


\section{EMPLOYMENT NEEDS}

\subsection{EMPLOYMENT NEEDS DURING OPERATION}

The CBF generally operates with three shifts per day, five days per week, except for some utility systems and security functions which operate continuously. The employment during operation is summarized in Table 5.1 The labor categories used in Table 5.1 are Equal Employment Opportunity (EEO) categories.

\subsubsection{Badged Employees at Risk of Radiological Exposure}

It is estimated that 60 of the badged employees are at risk of radiological exposure. In addition, a small fraction of badged visitors are expected to enter the radiological area, but this is on a nonroutine basis.

\subsubsection{Labor Category Descriptions}

The standard EEO labor categories in Table 5.1 are defined in the following paragraphs.

Officials and Managers. Occupations requiring administrative and managerial personnel who set broad policies, exercise overall responsibility for execution of these policies, and direct individual departments or special phases of a firm's operations. Included in this category are: officials, executives, middle management, plant managers, department managers and superintendents, purchasing agents, and buyers and salaried supervisors who are members of management.

Professionals. Occupations requiring either a college degree or experience of such kind and amount as to provide a comparable background. Included in this category are: accountants and auditors, architects, artists, chemists, designers, editors, engineers, lawyers, librarians, mathematicians, natural scientists, registered professional nurses, personnel and labor relation specialists, physical scientist, physicians, social scientists, and teachers.

Technicians. Occupations requiring a combination of basic scientific knowledge and manual skill which can be obtained through two years of post-high school education, such as is offered in many technical institutes and junior colleges, or through equivalent on-the-job training. Included in these occupations are: computer programmers, drafters, engineering aides, junior engineers, mathematical aides, licensed, practical or vocational nurses, photographers, radio operators, scientific assistants, surveyors, technical illustrators, and technicians (medical, dental, electronic, physical science). 
Table 5.1. Employment during surge operation

\begin{tabular}{|c|c|}
\hline I. & 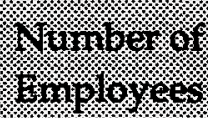 \\
\hline Officials and managers & 6 \\
\hline Professionals & 4 \\
\hline Technicians & 14 \\
\hline Office and clerical & 5 \\
\hline Craft workers & 23 \\
\hline Operatives & 49 \\
\hline Laborers & 4 \\
\hline Service workers & 21 \\
\hline TOTAL EMPLOYEES & 126 \\
\hline
\end{tabular}


Office and Clerical. This category includes all clerical work, regardless of level of difficulty, where the activities are predominantly non-manual, although some manual work not directly involved with altering or transporting the products is included. Included in this category are: bookkeepers, collectors (bills and accounts), messengers and office helpers, office machine operators (including computer), shipping and receiving clerks, stenographers, typists and secretaries, telephone operators, and legal assistants.

Craft Workers (skilled). Manual workers of relatively high skill level having thorough and comprehensive knowledge of the processes involved in their work. Exercise considerable independent judgment and usually receive an extensive period of training. Included in this category are: the building trades, hourly paid supervisors and lead operators who are not members of management, mechanics and repairers, skilled machining occupations, compositors and typesetters, electricians, engravers, painters (construction and maintenance), and pattern model makers.

Operatives (semiskilled). Workers who operate machine or processing equipment or perform other factory-type duties of intermediate skill level which can be mastered in a few weeks and require only limited training. Included in this category are: apprentices (auto mechanics, plumbers, bricklayers, carpenters, electricians, machinists, mechanics, building trades, metalworking trades, printing trades, etc.), attendants (auto service and parking), blasters, delivery workers, furnace workers, laundry operatives, milliners, motor operators, oilers and greasers (except auto), painters (manufactured articles), photographic process workers, stationary firefighters, truck drivers, welders and flamecutters, electrical and electronic equipment assemblers, inspectors, testers and graders, and handypackers and packagers.

Laborers (unskilled). Workers in manual occupations which generally require no special training who perform elementary duties that may be learned in a few days and require the application of little or no independent judgment. Included in this category are: garage laborers, car washers and greasers, groundskeepers and gardeners, stevedores, laborers performing lifting, digging, mixing, and loading and pulling operations.

Service Workers. Workers in both protective and non-protective service occupations. Included in this category. are: attendants (hospital and other institutions, professional and personal service, including nurses aides and orderlies), cooks, counter and fountain workers, elevator operators, firefighters and fire protection, guards, doorkeepers, stewards, janitors, police officers and detectives, recreation facilities attendants, guides, and public transportation attendants. 


\subsection{EMPLOYMENT NEEDS DURING CONSTRUCTION}

Employment needs during construction are presented in Table 5.2. 
Table 5.2. Number of construction employees needed by craft

\begin{tabular}{||l|c|}
\hline Carpenters & 13 \\
\hline Concrete masons & 11 \\
\hline Electricians & 24 \\
\hline Iron workers & 22 \\
\hline Laborers & 23 \\
\hline Millwrights & 18 \\
\hline Operators & 22 \\
\hline Sheet metal workers & 37 \\
\hline Pipefitters & 46 \\
\hline Sprinkler fitters & 19 \\
\hline Teamsters & 26 \\
\hline Other craftworkers & 9 \\
\hline Total craftworkers & 54 \\
\hline Construction management and & \\
\hline support staff & 323 \\
\hline Total Employment & \\
\hline
\end{tabular}


This page intentionally left blank. 


\section{WASTE AND EMISSIONS FROM THE PLANT}

\subsection{WASTE AND EMISSIONS DURING OPERATION}

This section presents the emissions and wastes generated by the CBF and supporting facilities during operation.

\subsubsection{Airborne Emissions}

The contaminated and potentially contaminated zones within the CBF facilities that handle uranium materials have high-efficiency particulate air (HEPA)-filtered ventilation systems that exhaust to the atmosphere. Some exhausts are provided with liquid scrubbing prior to HEPA filtration to remove chemical vapors such as nitric acid. The annual airborne emissions for the CBF are shown in Table 6.1.

\subsubsection{Solid and Liquid Waste}

The radioactive waste, hazardous/toxic waste, and non-hazardous sanitary waste are discussed in the subsections below. The annual quantity of solid and liquid waste generated by the CBF is shown in Table 6.2.

\subsubsection{Radioactive Waste}

Small amounts of low level radioactive waste and mixed waste are produced by the CBF. Radioactive waste consists primarily of scraped equipment, decontaimination solids, offgas treatment solids, metallic air filters, and HEPA filters. Mixed waste includes sludge immobilized in grout, contaminated aqueous liquids, and organic solvents.

\subsubsection{Hazardous Waste}

Liquid hazardous waste is stabilized and sent to an approved permitted RCRA disposal site.

\subsubsection{Nonhazardous Waste}

Solid nonhazardous waste generated at the CBF consist primarily of solid sanitary waste. Non-recyclable portions of this waste will be sent to the sanitary/industrial landfill. Quantities in Table 6.2 were generated as shown in Figures 3.2, 3.3, and 3.4. 
Table 6.1. Airborne emissions during operation - annual

\begin{tabular}{|c|c|}
\hline & Hom \\
\hline \multicolumn{2}{|c|}{ NONRADIOLOGICAL } \\
\hline Carbon monoxide & $2 \mathrm{MT}$ \\
\hline Nitrogen oxides & $0.4 \mathrm{MT}$ \\
\hline Ozone* & $0.2 \mathrm{MT}$ \\
\hline Particulate matter & $0.1 \mathrm{MT}$ \\
\hline \multicolumn{2}{|c|}{ RADIOLOGICAL } \\
\hline${ }^{235} \mathrm{U}$ & $1.1 \times 10^{-4}$ \\
\hline${ }^{238} \mathrm{U}$ & $6.2 \times 10^{4}$ \\
\hline
\end{tabular}

* Based on estimated generation of volatile organic chemicals (VOCs)

Table 6.2. Waste volumes during operation - annual

\begin{tabular}{|l|c|c|c|c|}
\hline & $\begin{array}{c}\text { Solid } \\
\left(\mathrm{m}^{3}\right)\end{array}$ & $\begin{array}{c}\text { Liquid } \\
(\mathrm{L})\end{array}$ & $\begin{array}{c}\text { Solid } \\
\left(\mathrm{m}^{3}\right)\end{array}$ & $\begin{array}{c}\text { Liquid } \\
(\mathrm{L})\end{array}$ \\
\hline Low-level waste & 145 & 49,000 & 8.51 & 0 \\
\hline Mixed low-level waste & 0 & 144,000 & 3.8 & 0 \\
\hline Hazardous waste & 0 & 5,970 & $<1$ & 0 \\
\hline Nonhazardous (sanitary) waste & 410 & $18,000,000$ & 590 & $17,800,00$ \\
\hline Nonhazardous (other) waste & 0 & $1,150,000$ & 0 & $1,160,000$ \\
\hline Recyclable waste & 410 & 0 & 410 & 0 \\
\hline
\end{tabular}




\subsection{WASTES AND EMISSIONS GENERATED DURING CONSTRUCTION}

This section presents the significant gaseous emissions and wastes generated by the CBF during construction.

\subsubsection{Airborne Emissions}

Air pollutants are emitted during CBF construction. The principal sources of such emissions are fugitive dust from land clearing, site preparation, excavation, and other construction activities as well as exhaust from construction equipment and vehicles delivering construction materials and carrying construction workers. The emissions generated during a peak construction year are shown in Table 6.3.

\subsubsection{Solid and Liquid Waste}

\subsubsection{Hazardous Waste}

There are no hazardous waste generated during construction.

\subsubsection{Nonhazardous Waste}

Nonhazardous solid and liquid waste generated during construction include concrete and steel waste construction materials and sanitary wastewater. The steel construction waste material will be recycled as scrap material before completing construction. The total wastes generated during construction are shown in Table 6.4. 
Table 6.3. Emissions during a peak construction year

\begin{tabular}{|c|c|}
\hline (8) & (2) \\
\hline \multicolumn{2}{|c|}{ CRITERIA POLLUTANTS } \\
\hline Sulfur dioxide & 0.5 \\
\hline Nitrogen dioxide & 2.0 \\
\hline Ozone* & 2.5 \\
\hline Carbon monoxide & 5.0 \\
\hline Particulate matter & 1.5 \\
\hline Total suspended particulates & 2.0 \\
\hline \multicolumn{2}{|c|}{ RADIOLOGICAL } \\
\hline${ }^{235} \mathrm{U}$ & 0 \\
\hline${ }^{238} \mathrm{U}$ & 0 \\
\hline
\end{tabular}

* Based on estimated generation of VOCs

Table 6.4. Total waste generated during construction

\begin{tabular}{||l|c|}
\hline Hazardous solids $\left(\mathrm{m}^{3}\right)$ & 0 \\
\hline Hazardous liquids $(\mathrm{l})$ & 0 \\
\hline Nonhazardous solids & 200 \\
\hline concrete $\left(\mathrm{m}^{3}\right)$ & 100 \\
\hline steel $(\mathrm{MT})$ & 4,000 \\
\hline sanitary $\left(\mathrm{m}^{3}\right)$ & 0 \\
\hline other & $3 \times 10^{6}$ \\
\hline Nonhazardous liquids & 0 \\
\hline sanitary (l) & \\
\hline other & \\
\hline
\end{tabular}




\section{HAZARDS DISCUSSION}

This chapter describes typical hazards associated with a CBF. Much of the data used in this chapter relates to HEU processing operations existing at the Y-12 Plant in Oak Ridge. Since these operations represent the technologies available for conversion and blending, and since the Y-12 Plant HEU processing operations have adequate production capacity, the hazards described herein can be considered applicable to the CBF that will blend down HEU as $\mathrm{UF}_{6}$.

Accident scenarios associated with the hazards at each operating CBF site may be different than those presented here. The development of more representative accident scenarios for each CBF site will depend on site specific factors such as:

- Design of blending process systems and process support systems

- Size, type, and proximity of equipment utilized in process and support systems

- Capacities of process and support systems to stage and process uranium and hazardous chemicals

- Engineered and administrative safety controls utilized in process and support systems

- Design, construction, and layout of utilities systems

- Design, construction, and layout of process buildings

- Potential impacts from other processes located inside process buildings and in nearby buildings

- Site and infrastructure layout

- Local natural phenomena hazards and meteorological conditions

- Public access to the site boundary

Currently, there are no facilities at the Y-12 Plant (for the handling, storing, or processing HEU) in Hazard Category (HC) 1, as defined in DOE Order 5480.28. The highest level determined for any processing facility at the Y-12 Plant is HC 2. It can therefore be assumed that the CBF located at any potential site will likewise be no higher than $\mathrm{HC} 2$. However, for conservatism the hazard information contained in this chapter assumes that the $\mathrm{CBF}$ will be $\mathrm{HC} 1$. 


\subsection{CBF HAZARD CONSIDERATIONS}

In assessing the bounding accident scenarios for the CBF, the following parameters were evaluated: 1) material at risk (MAR); 2) energy sources (fires, explosions, earthquakes, and process design-related events); 3) barriers to release; and 4) protective features of the facility. These parameters are discussed in the following sections.

\subsubsection{Material at Risk}

The CBF is typically a large multi-story structure devoted, wholly or partially, to converting and blending HEU with DU, NU, or LEU. The MAR consists of uranium metal, solutions, compounds, and $\mathrm{UF}_{6}$ gases at various enrichments from depleted to assays of $93 \%{ }^{235} \mathrm{U}$, and various non-radioactive reagents used in the process. The radioactive and non-radioactive hazardous materials used in significant quantities in the CBF processes are discussed below.

\subsubsection{Radioactive Hazardous Materials}

The only radioactive material processed in the CBF is uranium. The assumed isotopic content for uranium with different enrichments is shown in Table 7.1. From a hazards standpoint, all HEU (50\% enrichment) is assumed. The feed material is received in various forms ranging from retired metal parts to contaminated materials. Processing steps include size reduction, oxidation, dissolution, purification, denitration, reduction, hydrofluorination, fluorination and blending processes. The forms of HEU in these processes consist of:

- Metal and metal-contaminated materials

- Oxide powders and oxide-contaminated materials

- Fluoride powders

- Nitrate solids (powders and crystals)

- Nitrate solutions

- Organic solutions

- Uranium hexafluoride gas, liquid, and solid.

Table 7.2 lists the various radioactive materials in the facility that are at risk.

HEU and HEU compounds are stored, transported, and processed in criticality-safe containers. These include polyethylene and stainless steel tubular tanks for liquids and stainless or galvanized steel, cylindrical cans for solids. Metals, in particular, are stored within reinforced concrete vaults in locked steel boxes in fixed, safe arrays. Cans are transported in secured boxes mounted on dollies in fixed, safe arrays. 
Table 7.1. Isotopic content of uranium at various enrichments

\begin{tabular}{|c|c|c|c|c|c|c|}
\hline \multicolumn{7}{|c|}{ 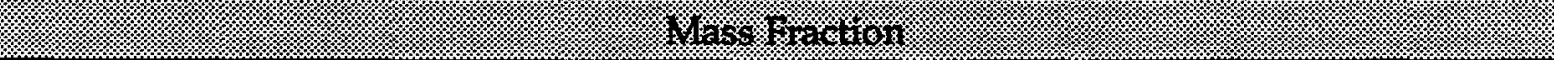 } \\
\hline Enrichment & ${ }^{232} \mathrm{U}$ & ${ }^{234} U$ & ${ }^{235} \mathrm{U}$ & ${ }^{236} \mathrm{U}$ & ${ }^{238} \mathrm{U}$ & Total \\
\hline $50 \%{ }^{235} \mathrm{U}$ & $4 \times 10^{-8}$ & $4.25 \times 10^{-3}$ & $5 \times 10^{-1}$ & $2.31 \times 10^{-3}$ & $4.93 \times 10^{-1}$ & 1.000 \\
\hline $4 \%{ }^{235} \mathrm{U}$ & $4 \times 10^{-8}$ & $3.34 \times 10^{-4}$ & $4 \times 10^{-2}$ & $1.54 \times 10^{-4}$ & $9.68 \times 10^{-1}$ & 1.000 \\
\hline $0.9 \%{ }^{235} \mathrm{U}$ & $4 \times 10^{-8}$ & $9.48 \times 10^{-5}$ & $9 \times 10^{-3}$ & $3.25 \times 10^{-5}$ & $9.91 \times 10^{-1}$ & 1.000 \\
\hline $0.71 \%{ }^{235} U$ & $4 \times 10^{-8}$ & $5.41 \times 10^{-5}$ & $7.11 \times 10^{-3}$ & 0 & $9.93 \times 10^{-1}$ & 1.000 \\
\hline $0.2 \%{ }^{235} \mathrm{U}$ & $4 \times 10^{-8}$ & $3.56 \times 10^{-5}$ & $2 \times 10^{-3}$ & 0 & $9.98 \times 10^{-1}$ & 1.000 \\
\hline \multicolumn{7}{|c|}{ 6. } \\
\hline & ${ }^{232} \mathrm{U}$ & ${ }^{234} U$ & ${ }^{235} \mathrm{U}$ & ${ }^{266} \mathrm{U}$ & ${ }^{238} \mathrm{U}$ & \\
\hline & $2.2 \times 10^{4}$ & 6.2 & $2.1 \times 10^{-3}$ & $6.3 \times 10^{-2}$ & $3.3 \times 10^{-4}$ & \\
\hline \multicolumn{7}{|c|}{ 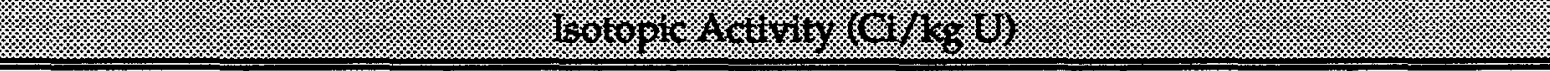 } \\
\hline Enrichment & ${ }^{202} \mathrm{U}$ & ${ }^{234} \mathrm{U}$ & ${ }^{235} \mathrm{U}$ & ${ }^{236} \mathrm{U}$ & ${ }^{238} \mathrm{U}$ & Total \\
\hline $50 \%{ }^{235} \mathrm{U}$ & $8.8 \times 10^{-4}$ & $2.64 \times 10^{-2}$ & $1.05 \times 10^{-3}$ & $1.46 \times 10^{-4}$ & $1.63 \times 10^{-4}$ & $2.86 \times 10^{2}$ \\
\hline $4 \%{ }^{235} \mathrm{U}$ & $8.8 \times 10^{-4}$ & $2.07 \times 10^{-3}$ & $8.4 \times 10^{-5}$ & $9.71 \times 10^{-6}$ & $3.17 \times 10^{-4}$ & $3.36 \times 10^{-3}$ \\
\hline $0.9 \%{ }^{235} \mathrm{U}$ & $8.8 \times 10^{-4}$ & $5.88 \times 10^{-4}$ & $1.89 \times 10^{-5}$ & $2.05 \times 10^{-6}$ & $3.27 \times 10^{-4}$ & $1.82 \times 10^{-3}$ \\
\hline $0.71 \%{ }^{235} \mathrm{U}$ & $8.8 \times 10^{-4}$ & $3.35 \times 10^{-4}$ & $1.49 \times 10^{-5}$ & 0 & $3.28 \times 10^{-4}$ & $1.56 \times 10^{-3}$ \\
\hline $0.2 \%{ }^{235} \mathrm{U}$ & $8.8 \times 10^{4}$ & $2.2 \times 10^{-4}$ & $4.2 \times 10^{-6}$ & 0 & $3.29 \times 10^{-4}$ & $1.43 \times 10^{-3}$ \\
\hline
\end{tabular}


Table 7.2. Materials at risk

\begin{tabular}{|c|c|c|}
\hline (1. & $8 x_{1} x_{3}$ & (2. \\
\hline \multicolumn{3}{|c|}{ SOLIDS } \\
\hline Potassium hydroxide & $1 \mathrm{MT}$ & Waste treatment $^{\mathrm{b}}$ \\
\hline Barium nitrate & $1.2 \mathrm{MT}$ & Dissolution $^{c}$ \\
\hline Sodium Fluoride & $0.1 \mathrm{MT}$ & HEU UF ${ }_{6}$ Collection \\
\hline HEU U/Al alloy, $25 \% \mathrm{U}, 75 \% \mathrm{Al}$ & $7 \mathrm{MT}$ & Storage warehouse \\
\hline HEU U/Al alloy, $25 \% \mathrm{U}, 75 \% \mathrm{Al}$ & $80 \mathrm{~kg}$ & Process feed \\
\hline Blend stock $\mathrm{UF}_{6}$, in cylinders & $50 \mathrm{MT}$ & New storage warehouse \\
\hline Blend stock $\mathrm{UF}_{6}$ in cylinders & $2.5 \mathrm{MT}$ & Process feed \\
\hline $\mathrm{HEU} \mathrm{UO}_{3}$, powder & $15 \mathrm{~kg}$ & HEU denitration \\
\hline HEU UF ${ }_{6}$ in cylinders ( $50 \%$ assay) & $50 \mathrm{~kg}$ & $\mathrm{UF}_{6}$ collection \\
\hline LEU UF $_{6}$ in cylinders ( $4 \%$ assay) & $5 \mathrm{MT}$ & Process product \\
\hline LEU UF $_{6}$ in cylinders ( $4 \%$ assay) & $55 \mathrm{MT}$ & New storage warehouse \\
\hline \multicolumn{3}{|c|}{ LIQUIDS } \\
\hline Propylene glycol & $400 \mathrm{~kg}$ & Size reduction \\
\hline Sodium hydroxide & $30 \mathrm{MT}$ & $\begin{array}{l}\text { Dissolution and waste } \\
\text { treatment } \\
\end{array}$ \\
\hline Sodium nitrate & $25 \mathrm{MT}$ & Dissolution $^{e}$ \\
\hline Dibutyl carbitol & $200 \mathrm{~kg}$ & Purification \\
\hline Tributyl phosphate (TBP) & $150 \mathrm{~kg}$ & Purification \\
\hline N-dodecane or high grade kerosene & $600 \mathrm{~kg}$ & Purification \\
\hline New nitric acid, $30 \%$ by weight & $40 \mathrm{MT}$ & Dissolution and purification ${ }^{a}$ \\
\hline Recovered nitric acid, $30 \%$ by weight & $5 \mathrm{MT}$ & Dissolution and purification $^{a}$ \\
\hline $\begin{array}{l}\text { HEU Uranyl nitrate solution; } \\
125 \mathrm{~g} / 1 \mathrm{U}, \sim 1.5 \mathrm{M} \mathrm{HNO}_{3}\end{array}$ & $200 \mathrm{~kg}$ & HEU dissolution \\
\hline $\begin{array}{l}\text { HEU uranyl nitrate solution; } \\
70 \mathrm{~g} / 1 \mathrm{U}, \sim 0.2 \mathrm{M} \mathrm{HNO}_{3}\end{array}$ & $300 \mathrm{~kg}$ & HEU purification \\
\hline HEU UF 6 , in cylinders (50\% assay) & $50 \mathrm{~kg}$ & HEU fluorination \\
\hline LEU UF $_{6}$, in cylinders ( $4 \%$ assay) & $5 \mathrm{MT}$ & Blending \\
\hline Blend stock UF ${ }_{6}$ in cylinders & $5.5 \mathrm{MT}$ & Process feed \\
\hline \multicolumn{3}{|c|}{ GASES } \\
\hline Argon & $<100 \mathrm{scf}$ & Blanket gas \\
\hline Nitrogen & $<100$ scf & Blanket gas \\
\hline Hydrogen & $<100$ scf & HEU reduction \\
\hline Anhydrous hydrogen fluoride & $600 \mathrm{~kg}$ & HEU hydrofluorination \\
\hline Fluorine & $500 \mathrm{~kg}$ & HEU fluorination \\
\hline HEU UF $_{6}$ in cylinder ( $50 \%$ assay) & $25 \mathrm{~kg}$ & HEU fluorination \\
\hline
\end{tabular}

a Quantities shown represent the estimated maximum amounts of these materials typically in process

b For scrubbing the denitration, hydrofluorination, and fluorination offgases.

c Used to precipitate other wise soluble carbonates.

d For dissolution of the U-Al alloy and for neutralizing the nitric acid in the purification operation raffinate.

e Used to suppress the evolution of hydrogen during the dissolution of Al by sodium hydroxide. 
Although all uranium materials are contained, accidents and natural phenomena that would release the contained materials can be postulated. The extent of release and suspension varies with the accident, container, and material form.

Metals are a special case. Due to security and criticality safety concerns, the uranium metal forms are stored in vaults providing substantial protection from accidents and natural phenomena. The secured concrete vaults and internal containers provide additional protection from the only (non-criticality) mechanism for suspending uranium metal, a fire which oxidizes the metal and suspends the oxide. Even if the metal were oxidized, the fraction of oxidized metal suspended would be approximately $10^{-4}$ to $10^{-5}$. Based on this small release fraction, the uranium metal stored in the secure vaults is not considered to be "at risk" of release. Uranium metal being processed at any time (outside the secure vaults) is assumed to be at risk in fire accidents and may contribute to nuclear criticality accidents.

\subsubsection{Nonradioactive Hazardous Materials}

The significant nonradioactive materials in the facility are listed in Table 7.2.

\subsubsection{Energy Sources}

The HC for the CBF, as defined in DOE Order 5480.28, has not been determined for HEU processing facilities at all potential sites. Facilities at the Y-12 Plant that are considered as candidate facilities for the CBF have been determined to be no higher than HC 2. It can therefore be assumed that the CBF located at any potential site will likewise be no higher than HC 2. However, the hazard information is based upon the conservative assumption that the $\mathrm{CBF}$ will be $\mathrm{HC} 1$. Therefore, criteria for $\mathrm{HC} 1$ facilities are provided below.

\subsubsection{Fires and Explosions}

The CBF may contain explosive/combustible materials, such as hydrogen and $\mathrm{N}$-dodecane/kerosene, as well as oxidizing, thermal, and electrical energy sources. Several chemical reactions can evolve hydrogen or potentially explosive nitrified organics (collectively referred to as "red oil"). However, the HVAC and process systems should prevent gases or red oil from accumulating to an explosive level. Table 7.3 presents the potential energy sources in the CBF. 
Table 7.3. Potential energy sources

\begin{tabular}{|l|l|l|}
\hline \hline Explosive/combustible & Hydrogen gas & Fluid bed \\
& Dibutyl carbitol & Primary extraction \\
& Tributyl phosphate (TBP) & Secondary extraction \\
& N-dodecane or kerosene & Secondary extraction \\
\hline Thermal & Steam & Evaporators \\
\hline Electrical & 2,400 volts & Utility services \\
\hline
\end{tabular}




\subsubsection{Earthquake}

DOE Order 5480.28 and DOE-STD-1020-94 specify the design basis earthquakes (DBE) and the natural phenomena performance goals for $\mathrm{HC} 1$ facilities at DOE sites. A beyond design basis earthquake should be evaluated in the accident analysis.

\subsubsection{Tornado}

DOE Order 5480.28 and DOE-STD-1020-94 specify the design basis tornadoes (DBT) and the natural phenomena performance goals for $\mathrm{HC} 1$ facilities at DOE sites. A beyond design basis tornado should be evaluated in the accident analysis.

\subsubsection{Flood}

DOE Order 5480.28 and DOE-STD-1020-94 specify the design basis flood (DBF) and the natural phenomena performance goals for $\mathrm{HC} 1$ facilities at $\mathrm{DOE}$ sites. A beyond design basis flood should be evaluated in the accident analysis.

\subsubsection{Nuclear Criticality}

The CBF contains multiple critical masses of uranium. Therefore, a criticality event cannot be ruled out, especially associated with a major earthquake or tornado.

\subsubsection{Process Design Related Events}

Process design related events include potential fires, explosions, and release of HF, $\mathrm{F}_{2}$ and $\mathrm{UF}_{6}$. No other significant process design-related events were identified.

\subsubsection{Barriers to Release}

The CBF utilizes a multibarrier system to prevent the release of radioactive and toxic materials to the atmosphere. The primary barriers include metal containers, gloveboxes/enclosures, and processing equipment, such as pencil tanks and piping. The secondary barriers include the building structure and the HVAC system.

Tanks, pans, storage cans, and other vessels contain the feed and products generated by the various systems. Since these processes may be batch operations, intermediate storage may be required.

Large volumes of solutions may be stored in tank arrays located in various places throughout the building. The tanks are stainless steel and have glass or stainless steel ends. They have an inner diameter of 5 to 6 in. and vary in length from 6 to 44 $\mathrm{ft}$. Due to spacing requirements, they are geometrically favorable containers for 
uranyl nitrate solutions. The tanks are normally vented, and overflows are generally connected to a common overflow manifold which empties to a safe bottle.

\subsubsection{Protective Features}

The CBF uses several protective features for personnel safety and radioactive material confinement during normal and accident operations. Ventilation systems barriers and nuclear criticality safety features are briefly discussed below.

Ventilation Barriers. Ventilation system barriers employed in the CBF range from hoods and enclosures for personnel protection to the processing of exhaust streams through filters and scrubbers to minimize releases. In general, filtration and scrubbing are used for exhausts from processes with a high potential for uranium release. Exhaust stacks are sampled to identify quantities of uranium released.

Criticality Safety. Active and passive design features are employed to prevent nuclear criticality. The principal feature employed is use of safe geometry piping, tanks, drains, and spill-retaining features of the process area floors. Uranium metals and powders are secured in metal-framed birdcages or inside concrete vaults to maintain criticality-safe spacing. A limited number of containers which are not safe geometry are provided with borosilicate rashig rings (neutron poison) to prevent criticality. In addition, radiation detectors and alarms are provided to allow rapid evacuation of personnel in the event of a criticality accident.

\subsection{ACCIDENT SCENARIOS CONSIDERED}

\subsubsection{Earthquake}

The DBE for the CBF site is assumed to be of sufficient magnitude to cause major damage to the building. A site-specific evaluation can demonstrate that a beyond design basis earthquake and total building collapse are not credible events

Building damage in the DBE would be accompanied by widespread failure of process vessels and piping. Organic solutions would be spilled to the floor where fires can result from various sources. Storage racks containing HEU cans or polyethylene bottles would be damaged by seismic shaking as well as falling debris. This would result in spillage of powders and liquids. A criticality can occur due to loss of safe spacing or due to aqueous or organic solutions reflecting neutrons into a layer of uranyl nitrate solution.

In the aftermath of such a large earthquake most emergency services, such as firefighting, are overburdened and may not be available for the CBF. The risk of 
spills, fires, and criticalities is great enough that this accident scenario can bound process related accidents and is therefore carried through for further analysis in Section 7.4.

\subsubsection{Tornado}

It is assumed that the DBT severely damages the exterior walls of the facility. Most damage occurs from missiles, such as pieces of pipe, and debris that the tornado picks up and propels through the air.

\subsubsection{Straight Wind}

A straight wind should be considered as an external initiating event. This can damage the buildings and some equipment, and possibly injure onsite personnel. The consequences, however, are lower than those caused by a tornado. Thus, the straight wind scenario is not a bounding scenario.

\subsubsection{Floods}

The BDF is assumed to be of sufficient magnitude to disrupt the perimeter of the CBF and cause water, under force, to contact the process equipment and materials. Process equipment may be damaged casing HEU dispersal into the building environment. Water may mix with $\mathrm{Heu}$ in potentially critical configurations.

\subsubsection{Aircraft Crash}

An aircraft crash is considered a bounding accident initiator because a crash of a large aircraft can: 1) penetrate a building wall or roof, 2) generate flying projectiles and missiles from building debris, building equipment, and aircraft debris, and 3) engulf a portion of the interior of a building in an aircraft fuel-fed fire. Although the local damage can be considerable, structural damage is expected to be much greater in the DBE. The exposed uranium within the building is in a number of diverse locations, so it is unlikely that more uranium will be exposed to an external flame source in the aircraft crash than the DBE.

A crash that penetrates any HEU storage vault area can expose the highly enriched uranium in the storage arrays to both severe impact, crushing, and fuel fire accident environments. Although a criticality is unlikely, a somewhat larger airborne uranium source term due to the fuel-fed fire burning of uranium metal can occur. On the other hand, the vault is a hardened structure and presents a very small cross section for an aircraft impact. 
Because a much more likely DBE probably bounds the consequences of any aircraft strike (except perhaps a direct hit by a large aircraft on the vault, and even in that case, the radiological consequences are not severe), the aircraft crash may be dismissed from further analysis.

\subsubsection{Truck Crash}

No significant offsite consequences can result from any reasonable truck crash at the CBF.

\subsubsection{Nuclear Criticality}

Based on reviews of typical operating practices in facilities similar to the CBF and of the criticality safety literature, there is a considerable margin of criticality safety for operations in the CBF. However, multiple critical masses of highly enriched uranium powder and solution within the building do not allow a criticality (while a low probability event) to be ruled out.

\subsubsection{Process Related Accidents}

Accidents that are considered as candidates for producing bounding releases of radioactivity from process related accidents are fires, explosions, nuclear criticality, and improper installation of the offgas filters on the fluidized bed reactor vessel. Accidents that can produce bounding releases of hazardous chemicals are the fluorine $\left(\mathrm{F}_{2}\right)$ release, hydrogen fluoride $(\mathrm{HF})$ release, nitric acid $\left(\mathrm{HNO}_{3}\right)$ sodium hydroxide $(\mathrm{NaOH})$ reactions, and $\mathrm{UF}_{6}$ release.

Fires involving uranium metal in process, combustible waste, uranium-bearing organic solutions, and the baghouse are possible. However, the organic solution fire and filter fire could be the most significant for the following reasons:

- The quantity of metal available for combustion in process and in wastes is small relative to the total facility inventory.

- The typical airborne release fraction (ARF) for metal fires is relatively small $\left(10^{4}\right.$ to $10^{-5}$ ) compared to other accidents (e.g., $3 \times 10^{-2}$ for uranium oxide powder suspension).

- The relative quantity of combustible waste, that is outside of containers and available to be involved in a fire, should be small.

The consequences of sequences of events leading to a red oil explosion are bounded by the organic solution fire. 
Failure to replace a fluidized bed exhaust filter during periodic changeout would result in uranium powders being discharged directly to the atmosphere by the process exhaust fans. The effects of this event are bounded by a $100 \%$ release of powder from the affected vessel directly to atmosphere. A small respirable fraction (RF) is estimated due to the coarse nature of the uranium oxides/fluorides.

A typical filter fire is significant because the air exhausted from the filter area (i.e., baghouse) flows directly to atmosphere with no filtration. If this accident were initiated by the DBE, the consequences would be less severe because the exhaust fans would not be operational. Thus, the filter fire with continued exhaust flow can a credible process accident.

Because significant quantities of hazardous chemicals are stored outside of the CBF and present a direct hazard to other onsite personnel, releases from the $\mathrm{F}_{2}, \mathrm{HF}$, and $\mathrm{HNO}_{3}$ and $\mathrm{NaOH}$ tanks should be considered. It is likely, however, that the only credible mechanism for significant simultaneous releases of these chemicals is the DBE.

\subsection{SELECTION OF BOUNDING ACCIDENT SCENARIOS}

With the exception of the fluidized bed exhaust filter event and the filter fire (with continuing exhaust flow), all the accident scenarios that are considered potentially bounding can be initiated by the DBE. Therefore it is concluded that the DBE results in the worst-case atmospheric release of radioactivity and/or hazardous chemicals.

\subsection{TYPICAL SOURCE TERMS}

The bounding event for release of radioactive and/or hazardous chemicals is the DBE. This single event initiates all of the release scenarios described in the following subsections with the exception of the fluidized bed exhaust filter event and the filter fire.

Specific values for releases are process and site-specific, and are not included here. Rather, the releases are identified. For each scenario described in the following subsections (other than nuclear criticality) all of the radioactivity that becomes airborne inside the building is released directly to atmosphere because of building damage; i.e., the leakpath factor (LPF) is equal to 1.0. 


\subsubsection{Release from Fluid Bed System}

Accident Description. This accident is initiated by a human error: two filters are removed from a single filter housing from a fluid bed gas outlet and are not replaced. This provides an open pathway for release of the contents of the fluid bed through the stack in the roof. The entire contents of one bed is pushed through this pathway by nitrogen gas.

A different accident can occur with this system if an operator fails to connect the pipe between the two fluid beds, then tries to transfer the powder. In this scenario, the entire contents of one bed is pushed out by the nitrogen gas into the room. This accident is less severe than the former because the material is released inside the building instead of on the roof and the LPF if $<1.0$.

\section{Key Assumption.}

An operator removes the high-temperature filters and then closes the filter housing without new filters inside.

Release Location. The release location is a stack on the roof of the CBF building.

Source Term. The fluid bed systems are run in a batch mode with either a mixture of $\mathrm{UO}_{3}$ and $\mathrm{UO}_{2}$ solid powders or $\mathrm{UO}_{2}$ and $\mathrm{UF}_{4}$ solid powders. It is assumed that both filters in either one of the two fluidized beds are inadvertently removed and not replaced. During the next bed operation, the process inventory is swept out of the bed and exhausted through the roof stack by the nitrogen used to fluidize the bed. The resulting source term is $\mathrm{HEU}$ principally in the form of $\mathrm{U}_{3} \mathrm{O}_{8}$ powder (the oxides and $\mathrm{UF}_{4}$ exposed to oxygen are assumed to oxidize to the $\mathrm{U}_{3} \mathrm{O}_{8}$ form).

\subsubsection{Filter Fire}

Accident Description. The major process exhaust from the CBF is filtered through bag filters and HEPA filters before being discharged to the atmosphere. Excess filtered material from the bag filters falls into traps below the filters. In this accident, a fire occurs which releases all the uranium in the bag filters, traps, and the HEPA filters to the atmosphere in a matter of minutes.

Energy Source. The energy sources for this accident are the uranium-containing dust, the wool bag filters, the paper HEPA filters, and the Lucite traps. All of these are combustible. An ignition source is assumed. 


\section{Key Assumptions.}

1. An ignition source exists.

2. Temperature detectors fail to close the dampers and activate fire extinguishing system.

3. The exhaust fans continue to operate.

4. All the material in the traps and bags and on the HEPA filters is assumed to become airborne.

Release Location. The release location is at the top of the filter location stack.

Source Term. Some bag filters can contain up to $1 \mathrm{~kg} \mathrm{HEU}$ each. Any HEU that is released is assumed to be released as $\mathrm{U}_{3} \mathrm{O}_{8}$ particles.

The direct release (DR) is 1.0 because the accident involves direct release of material from primary confinement. The amount of material that becomes airborne, however, is significantly less than the total amount.

\subsubsection{Nuclear Criticality}

Accident Description. Storage racks containing multiple critical masses of uranium powder and uranyl nitrate solution are damaged directly by seismic shaking and indirectly by falling debris. Safe spacing is lost and moderators added as water from the fire system or organic solutions resulting in the possible formation of one or more critical assemblies. Although this accident is not likely due to administrative controls, the limited use of metal storage racks, and the use of geometrically-safe containers, it is also possible to postulate a criticality event due to either mishandling of HEU-bearing solutions or equipment failure.

Energy Sources. If the event is initiated by the DBE, the energy sources are seismic shaking and falling debris.

Key Assumptions.

1. In an accidental criticality, it is assumed that $1 \times 10^{19}$ fissions occur prior to reaching a stable, subcritical condition. This total is comprised of an initial burst of $1 \times 10^{18}$ fissions followed by repeated bursts of $1 \times 10^{17}$ fissions over an 8-hr. period as liquid is assumed to be boiled from a solution system. 
2. Pools of spilled uranyl nitrate are unlikely to collect in critical dimensions because the absence of floor drains would allow spreading over large floor areas resulting in large surface-to-volume ratios and high neutron leakage. However, several loose polyethylene bottles containing HEU might form critical configurations. The same is true for other forms of HEU stored in cans.

3. Although most of the critical arrays that may be formed by the DBE are likely to be dispersed by the initial fission bursts, the occurrence of secondary bursts cannot be entirely ruled out. Further, the total number of criticalities cannot be predicted. Therefore, it is assumed that the total fission yield following DBEinduced criticalities is $1 \times 10^{19}$ occurring within a 2 -h period.

Release Location. The fission products from a nuclear criticality are released at ground level.

Source Term. Typical source terms (shown in Table 7.4) are taken from NRC Regulatory Guide 3.34.

\subsubsection{Natural Phenomena}

Accident Description The structural resistance of the CBF to natural phenomena must be evaluated. It is assumed that damage to the building is credible given a $\mathrm{DBE}, \mathrm{DBT}$, or DBF. Under this condition, the following impacts on the CBF are considered credible either individually or as a whole:

- Toppling containers not permanently fixed due to vibratory motion

- Crushing and rupturing containers due to falling debris

- Repositioning fissile materials into potentially critical arrays

- Rupturing building piping and external tanks resulting in the release of uranium solutions, water (a neutron moderator), toxic gases, flammable gases, and toxic and reactive liquids

- Creating multiple fire ignition sources due to damaged electrical equipment and high temperature process vessels

- Providing a moderator for fissile materials

Energy Sources. Most released materials are at ambient temperature. Energy sources include heats of combustion associated with uncontrolled chemical reaction, and energy release associated with nuclear criticality. 
Table 7.4. Typical atmospheric source terms for criticality

\begin{tabular}{|c|c|c|}
\hline 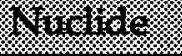 & 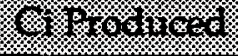 & 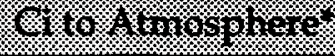 \\
\hline $\mathrm{Kr}-83 \mathrm{~m}$ & $1.6 \times 10^{2}$ & $1.6 \times 10^{2}$ \\
\hline $\mathrm{K} r-85 \mathrm{~m}$ & $1.5 \times 10^{2}$ & $1.5 \times 10^{2}$ \\
\hline $\mathrm{Kr}-85$ & $1.6 \times 10^{3}$ & $1.6 \times 10^{3}$ \\
\hline Kr-87 & $9.9 \times 10^{2}$ & $9.9 \times 10^{2}$ \\
\hline $\mathrm{Kr}-88$ & $6.5 \times 10^{2}$ & $6.5 \times 10^{2}$ \\
\hline $\mathrm{Kr}-89$ & $4.2 \times 10^{4}$ & $4.2 \times 10^{4}$ \\
\hline $\mathrm{Xe-131m}$ & 8.2 & $8.2 \times 10^{-2}$ \\
\hline$X e-133 m$ & 1.8 & 1.8 \\
\hline $\mathrm{Xe}-133$ & 27 & 27 \\
\hline $\mathrm{Xe}-135 \mathrm{~m}$ & $2.2 \times 10^{3}$ & $2.2 \times 10^{3}$ \\
\hline Xe-135 & $3.6 \times 10^{2}$ & $3.6 \times 10^{2}$ \\
\hline Xe-137 & $4.9 \times 10^{4}$ & $4.9 \times 10^{4}$ \\
\hline Xe-138 & $1.3 \times 10^{4}$ & $1.3 \times 10^{4}$ \\
\hline $\mathrm{I}-131$ & 8.7 & 2.2 \\
\hline $\mathrm{I}-132$ & $1.1 \times 10^{3}$ & $2.8 \times 10^{2}$ \\
\hline I-133 & $1.6 \times 10^{2}$ & 40 \\
\hline $\mathrm{I}-134$ & $4.5 \times 10^{3}$ & $1.1 \times 10^{3}$ \\
\hline $\mathrm{I}-135$ & $4.7 \times 10^{2}$ & $1.3 \times 10^{2}$ \\
\hline
\end{tabular}

Release time: $0-2 \mathrm{~h}$

*Building LPF = 1.0; ARF $=0.25$ for I, 1.0 for others 
Key Assumptions. Although specific combinations of effects of the DBE due to specified partial or complete building collapse accidents cannot be listed with any degree of completeness, the overall effects of this event type can be bound. The procedure used was to consider the effects on each MAR individually. The total source term was obtained by summing the individual releases for each material type. The following assumptions were made in this analysis:

1. Uranium Metal in Process $-10 \%$ of the total MAR is assumed oxidized (DR=0.1). For oxidation of uranium metal under turbulent conditions, the ARF is $1 \times 10^{-3}$ and the RF is 0.6 .

2. Uranium Fluoride or Oxide Powders - Spill of $10 \%$ of total MAR from an average height of $<3$ meters is assumed ( $D R=0.1$ ). In addition, the material not initially suspended is subject to aerodynamic resuspension for 24 hours (DR $=0.9$ ). The initial spill results in an ARF of $2 \times 10^{-3}$ with an RF of 0.2 . The aerodynamic resuspension rate results in an ARF of $8.6 \times 10^{-5}$ (based on a resuspension rate of $1 \times 10^{-9} \mathrm{sec}$ for $24 \mathrm{~h}$ ) with an RF of 1.0. This resuspension rate assumes the fallen debris limits the air flow velocities over a majority of the spilled powder.

3. Non-flammable Uranium Solutions in Process Tanks and Piping - Release of $100 \%$ of MAR from an average height of $<3$ meters creating a mist is assumed $(\mathrm{DR}=1.0$ ). This approximation bounds the fraction which may be suspended due to evaporation and the possibility of pressurized releases of some small fraction of tanks due to crushing. The ARF for this release is $1 \times 10^{-4}$ with an RF of 0.5 .

4. Non-flammable Uranium Solutions in Polyethylene Containers - 50\% of the MAR in polyethylene containers is assumed to leak and evaporate (or be resuspended) over $24 \mathrm{~h}$ in part due to heat inputs from fires (DR $=0.5$ ). In addition, $2 \%$ of the containers are assumed to be crushed, ejecting the liquid under pressure (DR = 0.02). The ARF and RF for resuspension of liquids are $8.6 \times 10^{-7}$ (based on a resuspension rate of $1 \times 10^{-11} / \mathrm{sec}$ for $24 \mathrm{~h}$ ) and 1.0. For pressurized releases of liquids, the $A R F$ is $1 \times 10^{-4}$ and the $R F$ is 1.0 .

5. Flammable (Organic) Uranium Solutions - Complete release, ignition, and combustion of the liquid solutions is assumed ( $D R=1.0$ ). Burning a large volume of a mixture of flammable and aqueous liquids containing dissolved uranium results in a ARF of $3 \times 10^{-2}$ with a RF of 1.0. Release and burning of organic and inorganic uranium solution mixtures is discussed in Subsection 7.4.5.

6. Combustible solids contaminated with uranium are assumed to be completely oxidized. The combustible solids are modeled as cellulosic material assuming 
the combustible solids are principally contaminated paper. The ARF and DR for this release are $5 \times 10^{-5}$ and 0.5 .

In addition to the suspension of the radioactive materials discussed above, other accidents are assumed to occur due to the building collapse in the same time frame. These accidents include release of the $\mathrm{F}_{2}$ and HF tank inventories (Subsections 7.4.6 and 7.4.7), and release and mixing of the $\mathrm{HNO}_{3}$ and $\mathrm{NaOH}$ tank inventories from the exterior storage tanks (Subsection 7.4.8).

Release Location. All releases are at ground level.

Source Term. Based on the MAR quantities and the assumptions and empirical suspension and respirable size fractions previously discussed, the total quantities of the hazardous materials suspended in the air due to postulated major building damage can be estimated. These estimates will yield the material-specific source terms for the building damage accident. Once suspended, the various uranium compounds react with oxygen and water vapor at high temperature (due to postulated fires) resulting in a final suspended mixture of compounds. The resulting source term is $\mathrm{HEU}$ mostly in the form of $\mathrm{U}_{3} \mathrm{O}_{8}$ powder (also from a solvent extraction fire). The additional source terms resulting from a postulated nuclear criticality are summarized in Table 7.4.

\subsubsection{Solvent Extraction Fire}

Accident Description. In the recovery and purification operations, uranium is recovered from uranyl nitrate solutions in an alternating series of purification and volume reduction steps followed by a series of chemical conversions that consolidate the uranium in the form of uranyl nitrate solution. A two-step purification is achieved by the use of two solvent extraction unit operations in series. In the primary extraction system, the HEU in the uranyl nitrate solution is extracted by the dibutyl carbitol solvent. In the secondary extraction system, the product stream from the primary extraction system is extracted by tributyl phosphate (TBP) in an ndodecane (or kerosene) diluent.

A fire is postulated to occur at the bottom of one of the secondary extraction columns due to a leak of TBP/diluent that ignites as a result of the DBE. The burning pool of organic material spreads to the remainder of the secondary extraction system. The heat generated by the burning pool causes the remaining secondary column to leak and add more organic material to the burning pool. The fire eventually propagates to the primary extraction system via the burning pool and the various feed and product tanks located on higher levels via a "chimney" effect through the openings where the columns are located. As the conflagration spreads, the nearby uranyl 
nitrate storage tanks also leak when their sight glasses crack or their gaskets burn. There is no automatic fire suppression system to prevent the spread of the fire.

Energy Source. The energy source for this accident is provided by the burning organic material. The dibutyl carbitol could also ignite after the fire propagates to the primary extraction system.

\section{Key Assumptions.}

1. The total inventory of combustible liquids is ignited.

2 No fire suppression (either automatic or manual) is available to prevent propagation of the fire to the primary extraction system and to other storage tanks located in the area.

3. The heat from the fire causes the concentrated aqueous uranyl nitrate solutions to evaporate at the same rate that the organic solutions are burning. Empirical data for fires involving aqueous/organic uranium solution mixtures suggests that this can occur. The uranium ARF used for this accident is appropriate for burning aqueous/organic mixtures.

4. All columns and tanks are filled to maximum capacity at the time that the fire occurs.

Release Location. The combustion products are released at ground level following an earthquake.

Source Term. HEU is present in organic solutions in various columns and tanks in the solvent extraction area. Additional HEU is present in uranyl nitrate solutions. This entire inventory is assumed to be the MAR. The DR is assumed to be 1.0 because the heat generated by the fire cause damage to all columns and tanks. The ARF for burning large volumes of nonvolatile liquids is 0.03 . The RF is 1.0 . The LPF is 1.0 because there is no filtration.

\subsubsection{Release of Fluorine}

Accident Description. An $F_{2}$ cylinder is connected to the process by a transfer line with a valve at each end. Should there be a major leak in the line or valving, a substantial quantity of $\mathrm{F}_{2}$ could leak. 
The bounding event caused by the DBE is the rupture of the $1 / 2$-in. pipe going through a wall at some height above the floor. Because the release occurs outside, there is no confinement barrier to airborne dispersion.

Energy Sources. The $F_{2}$ is at room temperature and is above atmospheric pressure. There are no other energy sources associated with the $F_{2}$ system.

Key Assumption.

The entire contents of the $\mathrm{F}_{2}$ cylinder are released.

Release Location. The release location is near ground level.

Source Term. The source term is gaseous $F_{2}$ ejected from the cylinder under pressure.

\subsubsection{Release of Hydrogen Fluoride}

Accident Description. The highly corrosive properties of HF make the possibility of gas leaks credible, particularly at piping junctions and valves. A major HF leak is more likely due to the DBE. Because the density of HF is slightly less than that of air, it will rise. The HF is supplied to the fluid beds from the HF Supply System. A typical system consists of a single liquid HF cylinder with a piping manifold that is connected to the $H F$ vaporizer. The $H F$ is transferred via pressurized $N_{2}$.

Energy Source. $\mathrm{HF}$ is transferred to the vaporizer by pressurized $\mathrm{N}_{2}$. There is no other energy source associated with the HF transfer operation.

Key Assumptions.

1. The HF tank is full.

2. The HF tank is completely emptied.

3. The HF vaporizes instantaneously as it is transferred out of the tank.

Release Location. The release location is at ground level.

Source Term. The source term is liquid HF spilled to the ground by pressurized $\mathrm{N}_{2}$. More than half of HF vaporizes within one hour. 


\subsection{8 $\mathrm{HNO}_{3}$ and $\mathrm{NaOH}$ Releases}

Accident Description. There is a high concentration nitric acid storage $\left(\mathrm{HNO}_{3}\right)$ tank and a sodium hydroxide $(\mathrm{NaOH})$ storage tank. These may be located in the same area. Should there be major leaks in lines or valves due to the DBE, substantial quantities of $\mathrm{HNO}_{3}, \mathrm{NaOH}$, or both can be spilled outside the building. The bounding accident is a spill of large quantities of $\mathrm{HNO}_{3}$ and $\mathrm{NaOH}$ that react with sufficient heat generation to result in significant quantities of airborne $\mathrm{HNO}_{3}$.

Energy Sources. The $\mathrm{HNO}_{3}$ and $\mathrm{NaOH}$ are at ambient temperature. The only significant energy source is the heat of reaction of $\mathrm{HNO}_{3}$ and $\mathrm{NaOH}$.

\section{Key Assumptions.}

1. The entire contents of the $\mathrm{HNO}_{3}$ and $\mathrm{NaOH}$ tanks are spilled.

2. The structural integrity of the curbing around the tank pits is compromised such that significant mixing occurs.

Release Location. The release location is outside, at ground level.

Source Term. The source terms are $30 \% \mathrm{HNO}_{3}$ and $20 \% \mathrm{NaOH}$. These chemicals react violently according to the reaction:

$\mathrm{HNO}_{3}+\mathrm{NaOH} \rightarrow \mathrm{NaNO}_{3}+\mathrm{H}_{2} \mathrm{O}$

The heat of reaction is sufficient to result in significant quantities of suspended, unreacted $\mathrm{HNO}_{3}$ vapor and mist.

\subsubsection{UF $_{6}$ Release}

Accident Description All $^{\mathrm{UF}_{6}}$ processing and handling takes place inside process equipment. Human errors or equipment failures associated with $\mathrm{UF}_{6}$ cylinder filling operations are the most likely causes of $\mathrm{UF}_{6}$ releases at the CBF. The bounding accident is a release of $\mathrm{UF}_{6}$ in the building and failure of the ventilation filtration system.

Energy Source. $\mathrm{UF}_{6}$ is released at above atmospheric pressure.

Key Assumptions.

1. Entire content of a $\mathrm{UF}_{6}$ cylinder is released. 
2. An DBE causes filtration system to fail.

Release Location. The release location is the facility stack.

Source Term. The source terms are $\mathrm{UF}_{6}, \mathrm{HF}$, and $\mathrm{UO}_{2} \mathrm{~F}_{2}$. 
This page intentionally left blank. 


\section{INTERSITE TRANSPORTATION}

The quantities of material to be shipped are summarized in Table 8.1 for $\mathrm{UF}_{6}$ blending.

If HEU alloy is shipped to the CBF, each SST shipment will hold approximately 385 $\mathrm{kg}$ of alloy ( $96 \mathrm{~kg} \mathrm{HEU).} \mathrm{For} 40 \mathrm{MT}$ of alloy of feed material, $105 \mathrm{SST}$ shipments per year or approximately nine SST shipments per month will be required.

If $1.5 \%$ assay $\mathrm{UF}_{6}$ blendstock is shipped to the $\mathrm{CBF}$, cylinders which hold $9000 \mathrm{~kg}$ of $\mathrm{UF}_{6}$ will be used. For a yearly supply of $272 \mathrm{MT}$ of $\mathrm{UF}_{6}, 30$ cylinders per year or approximately 2.5 cylinders per month will be required. At one cylinder per flatbed truck, three truckloads per month will be received.

If $4 \%$ assay $\mathrm{UF}_{6}$ product is shipped from the CBF to a commercial fuel fabricator, $2275 \mathrm{~kg} \mathrm{UF} 6$ cylinders would be used. For a yearly shipment of $287 \mathrm{MT}$ of $\mathrm{UF}_{6}, 126$ cylinders per year or approximately 11 cylinders per month will be shipped. At four cylinders per truck, three truckloads per month will be shipped. 
Table 8.1 Intersite transportation data - $\mathrm{UF}_{\mathbf{6}}$ blending

\begin{tabular}{|c|c|c|c|}
\hline \multirow{3}{*}{ trata } & \multicolumn{3}{|c|}{ Transporter Materit? } \\
\hline & \multicolumn{2}{|c|}{ 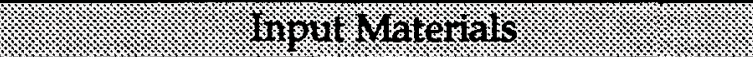 } & \multirow[t]{2}{*}{ 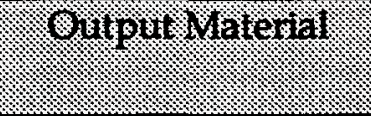 } \\
\hline & Blendsto. & HEI I Ied & \\
\hline Type & LEU & $\mathrm{HEU}$ & LEU \\
\hline Potential origin & $\begin{array}{l}\text { Paducah, KY } \\
\text { Portsmouth, OH }\end{array}$ & Oak Ridge, TN & $\begin{array}{l}\text { Lynchburg, VA } \\
\text { Erwin, TN }\end{array}$ \\
\hline Form & $\mathrm{UF}_{6}$ & Metal alloy & $\mathrm{UF}_{6}$ \\
\hline $\begin{array}{l}\text { Chemical } \\
\text { composition }\end{array}$ & $\begin{array}{l}\text { Pure UF } 61.5 \% \\
\text { assay }\end{array}$ & $\begin{array}{l}25 \% \text { HEU } \\
\text { (@ 50\% assay avg.) } \\
75 \% \text { Aluminum }\end{array}$ & Pure UF 6 (4\% assay) \\
\hline Annual quantity & $\begin{array}{l}272 \mathrm{MT} \mathrm{UF}_{6} \\
\text { (184 MT LEU) }\end{array}$ & $\begin{array}{l}40 \mathrm{MT} \text { alloy } \\
(10 \mathrm{MT} \mathrm{HEU})\end{array}$ & $\begin{array}{l}287 \mathrm{MT} \mathrm{UF}_{6} \\
\text { (194 MT LEU) }\end{array}$ \\
\hline \multirow{3}{*}{ Pata } & \multicolumn{3}{|c|}{ Packaging 6 Shippling. } \\
\hline & \multicolumn{2}{|c|}{ Tingur Materials } & 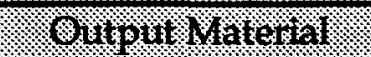 \\
\hline & Blendotor & IIIro ried. & \\
\hline Type & 10 Ton $U_{6}$ Cylinder & Drum & $\begin{array}{l}2.5 \text { Ton } \mathrm{UF}_{6} \\
\text { Cylinder }\end{array}$ \\
\hline Certified by & $\overline{\mathrm{DOE}}$ & $\overline{\mathrm{DOE}}$ & $\overline{\mathrm{DOE}}$ \\
\hline Identifier & $\begin{array}{l}48 \times \text { cylinder and } \\
\text { Paducah Tiger } \\
\text { overpack }\end{array}$ & $6 \mathrm{M}$ - Type B & $\begin{array}{l}30 \mathrm{~A} \text { cylinder and } \\
\text { PF21 overpack }\end{array}$ \\
\hline Package weight & $7,490 \mathrm{~kg}$ & $130 \mathrm{~kg}$ & $4,680 \mathrm{~kg}$ \\
\hline $\begin{array}{l}\text { Material weight } \\
\text { per package }\end{array}$ & $9,000 \mathrm{~kg} \mathrm{UF}_{6}$ & $\begin{array}{l}8 \mathrm{~kg} \text { alloy } \\
(2 \mathrm{~kg} \mathrm{HEU})\end{array}$ & $2,275 \mathrm{~kg} \mathrm{UF_{6 }}$ \\
\hline Packages/year & 30 & 5,000 & 126 \\
\hline Packages/truck & 1 & $48^{*}$ & 4 \\
\hline Trucks/year & 30 & 105 & 32 \\
\hline Potential destination & $\begin{array}{l}\text { Lynchburg, VA } \\
\text { Erwin, TN }\end{array}$ & $\begin{array}{l}\text { Lynchburg, VA } \\
\text { Erwin, TN }\end{array}$ & Fuel fabricator \\
\hline
\end{tabular}

* Packages per SST, one SST per truck. 


\section{ACRONYMS, ABBREVIATIONS, AND INITIALISMS}

\begin{tabular}{|c|c|}
\hline ALARA & As low as reasonably achievable \\
\hline ARF & Airborne release fraction \\
\hline ASTM & American Society for Testing and Materials \\
\hline $\mathrm{CBF}$ & Conversion and Blending Facility \\
\hline cfy & Cubic feet per year \\
\hline $\mathrm{Ci}$ & Curies \\
\hline $\mathrm{D} / \mathrm{N} / \mathrm{LEU}$ & Depleted, Natural, Low Enriched Uranium \\
\hline DBE & Design basis earthquake \\
\hline DBF & Design basis flood \\
\hline DBT & Design basis tornado \\
\hline DOE & Department of Energy \\
\hline DOT & Department of Transportation \\
\hline DR & Direct release \\
\hline DU & Depleted uranium \\
\hline EDE & Effective dose equivalent \\
\hline EEO & Equal Employment Opportunity \\
\hline EIS & Environmental Impact Statement \\
\hline EU & Enriched uranium \\
\hline ES\&H & Environmental, Safety, \& Health \\
\hline g & Gravitational acceleration \\
\hline gal & Gallons \\
\hline gpy & Gallons per year \\
\hline h & hour \\
\hline $\mathrm{HC}$ & Hazard category \\
\hline HAZ waste & Hazardous waste \\
\hline $\mathrm{HC}$ & Hazard Category \\
\hline HEPA & High-efficiency particulate air \\
\hline HEU & Highly enriched uranium \\
\hline $\mathrm{HF}$ & Hydrogen fluoride \\
\hline $\mathrm{HNO}_{3}$ & Nitric acid \\
\hline HVAC & Heating, ventilation, and air conditioning \\
\hline kg & Kilogram \\
\hline $\mathrm{KOH}$ & Potassium hydroxide \\
\hline L & Liter \\
\hline LEU & Low enriched Uranium \\
\hline LLW & Low-level waste \\
\hline LPF & Leak path factor \\
\hline LWR & Light water reactor \\
\hline $\mathrm{m}^{3}$ & Cubic meters \\
\hline MAA & Material Access Area \\
\hline MAR & Material at risk \\
\hline
\end{tabular}




\begin{tabular}{|c|c|}
\hline MIX waste & Mixed waste \\
\hline MT & Metric ton \\
\hline MW & Megawatt \\
\hline MWh & Megawatt hour \\
\hline NRC & Nuclear Regulatory Commission \\
\hline NU & Natural uranium \\
\hline ORR & Oak Ridge Reservation \\
\hline PEIS & Programmatic Environmental Impact Statement \\
\hline $\begin{array}{l}\text { PIDAS } \\
\text { psia }\end{array}$ & $\begin{array}{l}\text { Perimeter Intrusion Detection and Assessment System } \\
\text { pounds per square inch absolute }\end{array}$ \\
\hline RAD waste & Low-level radioactive waste \\
\hline RCRA & Resources Conservation and Recovery Act \\
\hline $\mathrm{RCW}$ & Recirculating cooling water \\
\hline RF & Respirable fraction \\
\hline SAN waste & Sanitary waste \\
\hline $\operatorname{scf}$ & Standard cubic feet \\
\hline SNM & Special nuclear material \\
\hline SST & Safe secure trailer \\
\hline TBP & Tributyl phosphate \\
\hline $\mathrm{U}$ & Uranium \\
\hline $\mathrm{U} / \mathrm{Al}$ & Uranium/aluminum \\
\hline UCRL & University of California Research Laboratory \\
\hline $\mathrm{UF}_{4}$ & Uranium tetrafluoride \\
\hline $\mathrm{UF}_{6}$ & Uranium hexafluoride \\
\hline UN & Uranyl nitrate \\
\hline UNH & Uranyl nitrate hexahydrate \\
\hline $\mathrm{UO}_{2}$ & Uranium dioxide \\
\hline $\mathrm{UO}_{3}$ & Uranium trioxide \\
\hline $\mathrm{U}_{3} \mathrm{O}_{8}$ & Triuranium octoxide \\
\hline USEC & United States Enrichment Corporation \\
\hline VOC & Volatile organic chemical \\
\hline
\end{tabular}




\section{Appendix A: Blending Assumptions and Limitations}

As described in Section 1.1, the primary mission of the CBF is to destroy the weapons capability of surplus HEU by blending with a lower ${ }^{25} \mathrm{U}$ assay uranium material to achieve a level below $20 \%{ }^{235} \mathrm{U}$. In most cases the blending will be carried to a final assay of $4.0 \%{ }^{235} \mathrm{U}$ in order to utilize the product as LWR fuel. In cases where the surplus HEU is not suitable for LWR fuel use, because of excessively high concentrations of undesirable minor uranium isotopes $\left({ }^{234} U\right.$ and $\left.{ }^{236} U\right)$, the HEU will be blended down to $0.9 \%{ }^{225} \mathrm{U}$ for long-term storage or disposal as waste. In all cases, the reduction of assay is irreversible.

Four technology options are considered in EIS documents for the disposition of surplus HEU by blending: (1) metal blending; (2) UNH blending; (3) $\mathrm{UF}_{6}$ blending; and (4) oxide blending. This appendix lists key assumptions used in the process descriptions for the four blending options. These assumptions are shown in Table A.1. A comprehensive logic block flow diagram showing the decisions involved in processing different HEU feed materials, using all four blending options, is shown in Figure A.1.

Any one of the four options can be utilized for uranium disposition. Metal blending, however, will not be considered if the resulting product is intended for LWR fuel. Metallic LEU would require fuel fabricators to add the capability for dissolving the metal. Fuel fabricators generally receive LEU as $\mathrm{UF}_{6}$ from enrichment plants and that form will be their first choice from blending operation. In the EIS documents, metal blending applies only to blending surplus HEU which is determined to be unsuitable for LWR fuel and for which the blended product goes into long-term storage or is disposed of as waste.

On the other hand, $\mathrm{UF}_{6}$ blending is practical only if the product is intended for LWR fuel rather than a waste product. For $\mathrm{UF}_{6}$ to be considered for long-term storage or disposal as waste, its conversion to an oxide is required. A potential negative factor with using $\mathrm{UF}_{6}$ is that none of the surplus HEU is currently in $\mathrm{UF}_{6}$ form and conversion to $\mathrm{UF}_{6}$ requires the construction of new facilities.

Oxide blending and UNH blending are applicable for both LWR fuel production and preparation of material for long-term storage or disposal as waste. It may be possible for the fuel fabricators to accept limited quantities of blended LEU as either UNH crystals or oxide, which they can process through their scrap recovery lines.

Surplus HEU may exist in various chemical and physical forms with different chemical and isotopic impurities. Certain technological or economic factors may favor one of the four options for one batch and another option in other cases. No one option may prove to be economically viable for disposition of the entire surplus HEU inventory. Table A.2 summarizes the characteristics of both the HEU and the low assay diluent associated with each blending option and intended product. 
- Chemical and isotopic analysis of discrete batches of surplus HEU should enable advance determination of whether the material can be blended to produce marketable LWR fuel or must be blended for long-term storage/waste disposal.

- Surplus HEU which is determined suitable for LWR fuel use shall be blended to a final product assay of $4.0 \%{ }^{235} \mathrm{U}$.

- The 4.0\% blended product for LWR fuel use shall be provided in the form of pure $\mathrm{UF}_{6}, \mathrm{UNH}$ crystals, or oxide that comply with material standards.

- Blending as metal will only be considered for surplus HEU metal and alloy that is not suitable for conversion to LWR fuel.

- Surplus HEU which is determined unsuitable for LWR fuel use shall be blended to a final product assay of $0.9 \%{ }^{235} \mathrm{U}$.

- The $0.9 \%$ blended product for long-term storage/waste disposal shall be provided in the form of oxide, metal, or alloy.

- Blending as $\mathrm{UF}_{6}$ shall not be considered for any surplus HEU which is determined unsuitable for LWR fuel.

- For each blending option, the annual process capability is defined by the requirement to blend up to $10 \mathrm{MT}$ of surplus HEU at an average assay of $50 \%$ to a final product assay of $4.0 \%$. [This same product mass throughput rate shall also apply if the blended product is $0.9 \%$; in this case a lesser HEU consumption would result.]

- Capability for purification of the incoming HEU stream using solvent extraction of UNH solution shall be provided except in the case of metal blending, which is applicable only for long-term storage/waste disposal.

- Adequate supplies of low assay diluent are available in appropriate chemical forms, with the following restrictions: (a) if LEU diluent is used, it is only available as $\mathrm{UF}_{6}$; (b) if NU diluent is used, it is available either as $\mathrm{UF}_{6}$ or as oxide; (c) if DU diluent is used, it is available as $\mathrm{UF}_{6}$ oxide, or metal.

- No purification will be required for the incoming low assay diluent stream. 


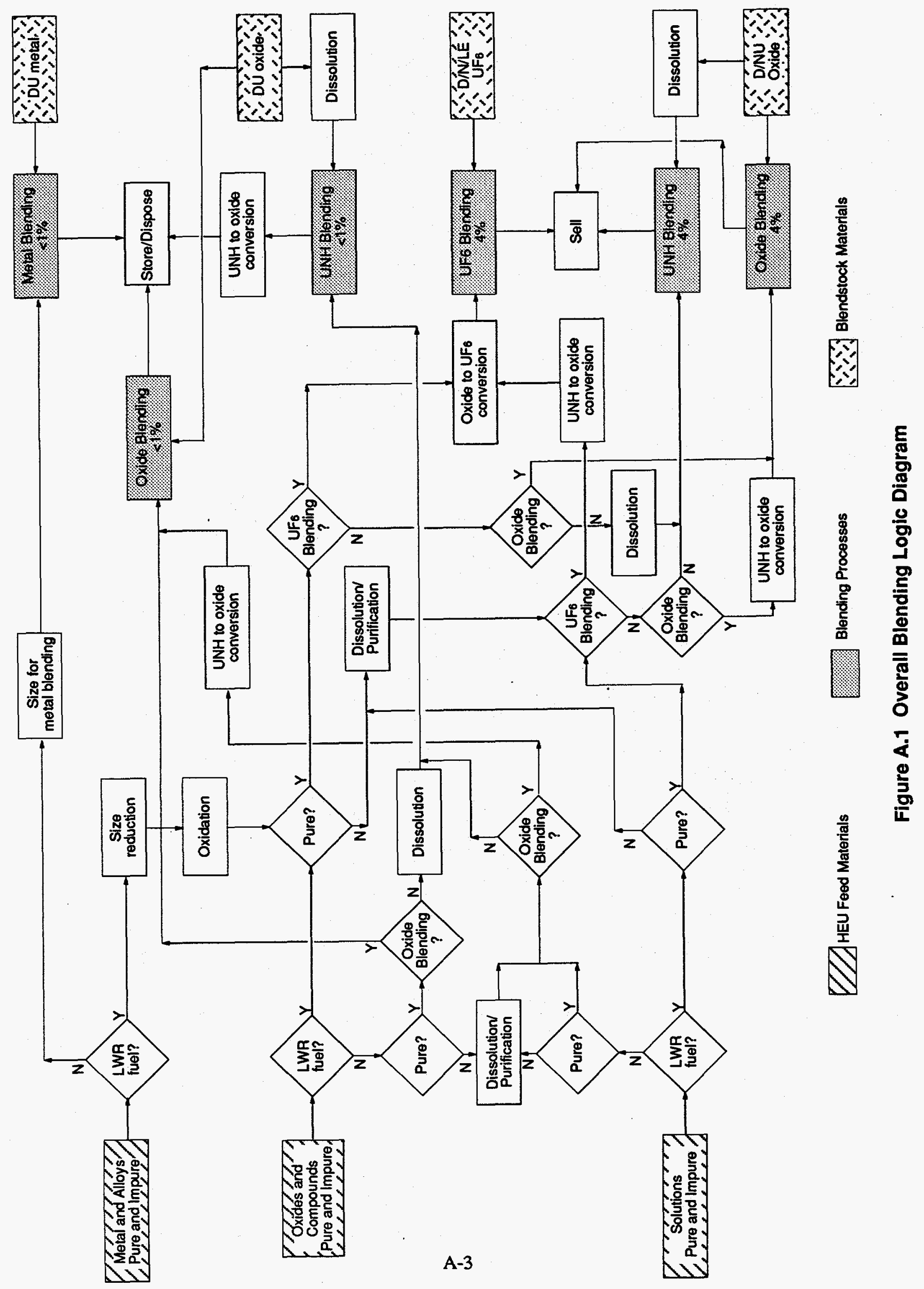


Table A.2. Feed streams for various disposition options

\begin{tabular}{|c|c|c|}
\hline (19is & 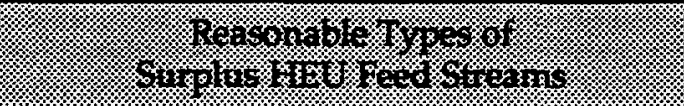 & 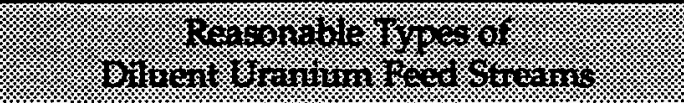 \\
\hline $\begin{array}{l}\text { Blending as } \\
\text { metal for } \\
\text { storage or } \\
\text { disposal }\end{array}$ & $\begin{array}{l}\text { Metal } \\
\text { - high concentrations of }{ }^{234} U \text { or }{ }^{236} U \\
\text { - all HEU assays } \\
\text { - alloyed or unalloyed } \\
\text { - } \quad \text { all levels of chemical impurities }\end{array}$ & $\begin{array}{l}\text { Metal } \\
\text { - DU } \\
\text { - all concentrations of }{ }^{234} U \text { and }{ }^{236} U \\
\text { - } \quad \text { unalloyed (alloyed if available) } \\
\text { - all levels of chemical impurities }\end{array}$ \\
\hline $\begin{array}{l}\text { Blending as } \\
\text { oxide for } \\
\text { storage or } \\
\text { disposal }\end{array}$ & $\begin{array}{l}\text { Oxide } \\
\text { - high concentrations of }{ }^{234} U \text { or }{ }^{236} U \\
\text { - all HEU assays } \\
\text { - all levels of chemical impurities }\end{array}$ & $\begin{array}{l}\text { Oxide } \\
\text { - DU } \\
\text { - all concentrations of }{ }^{234} U \text { and }{ }^{236} U \\
\text { - all levels of chemical impurities }\end{array}$ \\
\hline $\begin{array}{l}\text { Blending as } \\
\text { UNH for } \\
\text { storage or } \\
\text { disposal }\end{array}$ & $\begin{array}{l}\text { Oxide, } U N H, \& \text { miscellaneous compounds } \\
\text { - high concentrations of }{ }^{24} U \text { or }{ }^{236} U \\
\text { - all HEU assays } \\
\text { - all levels of chemical impurities }\end{array}$ & $\begin{array}{l}\text { Metal \& oxide } \\
\text { - DU } \\
\text { - all concentrations of }{ }^{24} U \text { and }{ }^{236} U \\
\text { - } \text { unalloyed metal (alloyed if available) } \\
\text { - all levels of chemical impurities }\end{array}$ \\
\hline $\begin{array}{l}\text { Blending as } \\
\text { oxide for } \\
\text { LWR fuel }\end{array}$ & $\begin{array}{l}\text { Metal \& oxide } \\
\text { - low concentrations of }{ }^{24} U \text { and }{ }^{236} U \\
\text { - all HEU assays } \\
\text { - } \quad \text { unalloyed metal } \\
\text { - all levels of chemical impurities }\end{array}$ & $\begin{array}{l}\text { Oxide } \\
\text { - DU or NU } \\
\text { - low concentrations of }{ }^{234} U \text { and }{ }^{236} U \\
\text { - low levels of chemical impurities }\end{array}$ \\
\hline $\begin{array}{l}\text { Blending as } \\
\text { UNH for } \\
\text { LWR fuel }\end{array}$ & $\begin{array}{l}\text { Metal, oxide, UNH, \& miscellaneous } \\
\text { compounds } \\
\text { - low concentrations of }{ }^{234} U \text { and }{ }^{236} U \\
\text { - all HEU assays } \\
\text { - alloyed or unalloyed metal } \\
-\quad \text { all levels of chemical impurities }\end{array}$ & $\begin{array}{l}\text { Metal \& oxide } \\
\text { - DU or NU } \\
\text { - low concentrations of }{ }^{24} U \text { and }{ }^{236} U \\
\text { - unalloyed metal } \\
\text { - low levels of chemical impurities }\end{array}$ \\
\hline $\begin{array}{l}\text { Blending as } \\
\text { UF }_{6} \text { for } \\
\text { LWR fuel }\end{array}$ & $\begin{array}{l}\text { Metal, oxide, UNH, \& miscellaneous } \\
\text { compounds } \\
\text { - low concentrations of }{ }^{234} U \text { and }{ }^{26} U \\
\text { - all HEU assays } \\
\text { - alloyed or unalloyed metal } \\
\text { - all levels of chemical impurities }\end{array}$ & $\begin{array}{l}U_{6} \\
\text { - DU, NU, or LEU } \\
\text { - low concentrations of }{ }^{24} U \text { and }{ }^{236} U \\
\text { - low levels of chemical impurities }\end{array}$ \\
\hline
\end{tabular}


Distribution:

D. H. Andrews, LLNL

H. R. Canter, DOE-MD

Y-12 Central Files, 9711-5, MS-8269

S. O. Cox

A. I. Cygleman, DOE-HQ

R. D. Duncan, DOE-HQ

B. G. Eddy, DOE-ORO

D. A. Everitt,DMC-RC

C. D. Jaeger, SNL

J. N. Kass. LLNL

A. K. Lee/DOE-OSTI, 9731, MS-8175 (2)

M. A. Livesay, DOE-ORO

D. L. Mangan, SNL

C. A. Pura, SNL-TI

J. D. Snider

J. D. Stout

B. Swedock

J. W. Toevs, LANL

T. H. Wynn, DOE-ORO 